\section{Consenvation}

-

Division of Buildings

and

Community Systems

\title{
Residential Energy Use to the Year 2000: Conservation and Economics
}

\author{
Eric Hirst \\ Janet Carney
}




\section{DISCLAIMER}

This report was prepared as an account of work sponsored by an agency of the United States Government. Neither the United States Government nor any agency Thereof, nor any of their employees, makes any warranty, express or implied, or assumes any legal liability or responsibility for the accuracy, completeness, or usefulness of any information, apparatus, product, or process disclosed, or represents that its use would not infringe privately owned rights. Reference herein to any specific commercial product, process, or service by trade name, trademark, manufacturer, or otherwise does not necessarily constitute or imply its endorsement, recommendation, or favoring by the United States Government or any agency thereof. The views and opinions of authors expressed herein do not necessarily state or reflect those of the United States Government or any agency thereof. 


\section{DISCLAIMER}

Portions of this document may be illegible in electronic image products. Images are produced from the best available original document. 


\section{Printed in the United States of America. Available from National Technical Information Service \\ U.S. Department of Commerce 5285 Port Royal Road, Springfield, Virginia 22161 \\ Price: Printed Copy $\$ 4,60 ;$ Microfiche $\$ 3.00$}

This report was prepared as an account of work sponsored by the United States Government. Neither the United States nor the Energy Research and Development Administration/United States Nuclear Regulatory Commission, nor any of their employees, nor any of their contractors, subcontractors, or their employees, makes any warranty, express or implied, or assumes any legal liability or responsibility for the accuracy, completeness or usefulness of any information, apparatus, product or process disolosed, or represents that its uso would not infringe privatoly owned rights. 
ORNL/CON-13

Contract No. W-7405-eng-26

ENERGY DIVISION

RESIDENTIAL ENERGY USE TO THE YEAR 2000: CONSERVATION AND ECONOMICS

$$
\begin{aligned}
& \text { Eric Hirst } \\
& \text { Janet Carney }
\end{aligned}
$$

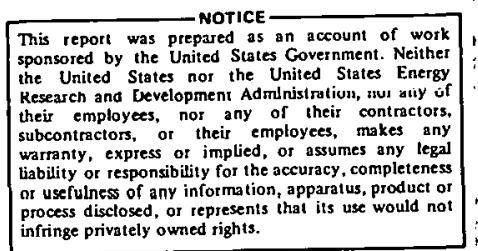

This report was prepared as an account of work sponsored by the United Slates Government. Neither any of their contractors

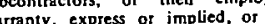
infringe privately owried tights.

Work supported by the Federal Energy Administration and the Energy Research and Development Administration

Date Published: September 1977

\author{
OAK RIDGE NATIONAL LABORATORY \\ Oak Ridge, Tennessee 37830 \\ operated by \\ UNION CARBIDE CORPORATION \\ for the \\ ENERGY RESEARCH AND DEVELOPMENT ADMINISTRATION
}


THIS PAGE

\section{WAS INTENTIONALLY LEFT BLANK}


RESIDENTIAL ENERGY USE TO THE YEAR 2000: CONSERVATION AND ECONOMICS

Eric Hirst

Janet Carney

\begin{abstract}
This report evaluates the energy and direct economic effects of implementing various residential energy conservation programs. These evaluations are conducted using a detailed engineering-economic model that simulates residential energy use on an annual basis from 1970 through 2000. These programs include several authorized by the $94 \mathrm{th}$ Congress and expanded upon by the present administration: appliance efficiency standards, thermal standards for construction of new residences, and weatherization of existing housing units. In addition to these federal programs that are being (or will be) implemented in some form, we consider two additional measures to save energy: large fuel price increases and elimination of all market imperfections associated with the production and purchase of new equipment and homes. Altogether, nine different residential energy "futures" are considered.
\end{abstract}

The highest projection, which assumes constant real fuel prices from 1976-2000, shows residential energy use growing from 16 QBtu in 1976 to 28 QBtu in 2000, with an average annual growth rate of $2.3 \%$. The baseline, which assumes rising fuel prices, yields an energy use estimate of $24 \mathrm{QBtu}$ in 2000. Implementing all the federal programs listed above would cut energy use in 2000 by $11 \%$, to 22 QBtu. Adopting these programs also reduces energy-related costs to households by $\$ 27$ billion.

Raising fuel prices by 50\% after 1984 and eliminating all market imperfections yields essentially zero energy growth in the residential sector. However, the cost to households of higher fuel prices amounts to about $\$ 60$ billion. 
THIS PAGE

\section{WAS INTENTIONALLY LEFT BLANK}


CONTENTS

$\underline{\text { Page }}$

ABSTRACT ........................... . . . . . . . . . . . . . .

1. INTRODUCTION . . . . . . . . . . . . . . . . . . . . 1

2. HISTORY . . . . . . . . . . . . . . . . 3

3. HIGH ENERGY USE PROJECTION . . . . . . . . . . . . . . . . . 11

4. BASELINE PROJECTION . . . . . . . . . . . . . . . . 14

5. FEDERAL CONSERVATION PROGRAMS . . . . . . . . . . . . . . 18

Appliance Efficiency Targets . . . . . . . . . . . 20

New Construction Standards . . . . . . . . . . . 25

Retrnfit Prngram . . . . . . . . . . . . . . . . 28

Combined Federal Program . . . . . . . . . . . . 30

6. ADDITIONAL PROGRAMS .................. . . 33

Higher Fuel Prices. . . . . . . . . . . . . . . . 34

Elimination of Market Imperfections . . . . . . . . 36

Higher Fuel Prices and Elimination of

Market Imperfections . . . . . . . . . . . . . 37

7. SUMMARY . . . . . . . . . . . . . . . . 38

ACKNOWLEDGMENTS . . . . . . . . . . . . . . . . . . . . . . . 42

REFERENCES .......................... . . . . 43

APPENDIX: Market Penetration Analysis in the ORNL Residential

Energy Use Model . . . . . . . . . . . . . . . 
RESIDENTIAL ENERGY USE TO THE YEAR 2000: CONSERVATION AND ECONOMICS

Eric Hirst

Janet Carney

\section{INTRODUCTION}

This report addresses two key issues concerning residential energy conservation strategies: their effects on energy use trends and on household economics. Our conclusions concerning these issues are:

(1) Future levels of residential energy use are subject to considerable control; the analyses reported here show a range in energy use in the year 2000 of $16 \mathrm{QBtu}$ to $28 \mathrm{QBtu}$. ${ }^{*}$ Thus, conservation programs can provide considerable reductions in residential energy use.

(2) Implementing conservation programs generally saves money for consumers; for example, the programs proposed by President Carter in his April 20, 1977 energy message ${ }^{l}$ are estimated to save households $\$ 27$ billion between now and the year 2000 .

The basis for these conclusions is a set of analyses prepared with a detailed engineering-economic model of residential energy use developed at ORNL. ${ }^{2}$ This model simulates household energy use at the national level for four fuels, eight end uses, and three housing types. Each of these 96 fuel use components is calculated for each year of the simulation as functions of: stocks of occupied housing units and new construction, equipment uwlership by fuel and end use, thermal integrity of

*Quantities are given in British units. 1 QBtu $=1$ Quad $=10^{15}$ Btu. $1 \mathrm{Btu}=1,055$ joules. Electricity use figures are in terms of primary energy $(11,500 \mathrm{Btu} / \mathrm{kWh})$; that is they include losses in generation, transmission, and distribution. Figures for gas and oil do not include losses associated with refining and transportation. 
housing units, average unit energy requirements for each type of equipment, and usage factors that reflect household behavior. The model also calculates annual fuel expenditures, equipment costs, and capital costs for improving thermal integrity of new and existing structures at the same level of detail. These cost figures allow us to develop simple benefit/cost measures for each program evaluated.

Nine different residential energy "futures" are evaluated with the ORNL residential energy model. The first (high projection) assumes that "real" fuel prices remain constant from 1976 through the end of the century and that no federal conservation programs are adopted.

In the second case, fuel prices are allowed to rise between 1976 and 2000. Again, no government conservation programs are implemented. Changes in energy use are entirely voluntary and come about because of normal market forces only. This second case is considered our "baseline," against which all the other cases are compared.

The next four cases consider the residential conservation programs. authorized by the 94th Congress and expanded upon in the Aprii 1977 energy message: appliance efficiency standards, thermal performance standards for new construction, a retrofit program to affect $90 \%$ of the nation's housing stock, and the combination of these three programs.

The last three cases consider the energy and economic effects of additional conservation programs: much larger fuel price increases, elimination of all market imperfections affecting residential energy use, and both.

Each program and policy is evaluated for its effects on residential energy use (by fuel, end use, and in aggregate) and on household economics 
(fuel bills, capital costs for equipment and structures) between 1977 and 2000. Tables 1 and 2 briefly summarize the energy and economic effects of each of the nine cases discussed here.*

The remainder of this report is organized as follows. Section 2 reviews historical trends in residential energy use. Section 3 describes the inputs for our high projection and the consequent outputs from the ORNL model. Section 4 presents the baseline projection. Section 5 reviews the conservation programs authorized by the 94 th Congress and the President's proposed modifications, and the likely effects of implementing these programs. Section 6 discusses the stronger programs mentioned above and their energy and economic consequences. Finally, section 7 reviews the different futures and summarizes the likely effects of each.

We also include an appendix to explain the market penetration portion of our energy use simulation model. Other details on the structure and operation of our model are in ref. 2 .

\section{HISTORY}

Table 3 shows residential fuel use from 1950 through $1975^{\text {l' }}$ for electricity, gas petroleum products (kerosine and fuel oil), and other

\footnotetext{
* Although the results of our projections are given here as certainties, there is considerable uncertainty about what will happen by the year 2000. Part of the uncertainty relates to the exogenous varlables such as fuel prices and population. The rest relates to the model itself, both its structural form and the particular coefficients used in the model equations.

${ }^{\dagger}$ Preliminary figures ${ }^{4}$ for residential energy use in 1976 are: 7.3 QBtu electricity, 5.7 QBtu gas, 3.4 QBtu oil, and $0.6 \mathrm{QBtu}$ other fuels for a tota1 of 17.0 QBtu. This is a 4.7\% increase over the 1975 total of 16.2 QBtu. The model's estimate of 16.3 QBtu for 1976 is $4 \%$ lower than the preliminary Bureau of Mines number.
} 
Table 1. Alternative residential energy use projections: energy use

\begin{tabular}{|c|c|c|c|c|c|c|c|}
\hline \multirow[b]{2}{*}{$\begin{array}{l}\text { Run } \\
\text { no. }\end{array}$} & \multirow[b]{2}{*}{ Description } & \multicolumn{5}{|c|}{ Energy use (QBtu) } & \multirow{2}{*}{$\begin{array}{l}\text { Average annual } \\
\text { growth rate, } \\
1976-2000(\%) \text { a }\end{array}$} \\
\hline & & 1980 & 1985 & 1990 & 2000 & $\begin{array}{l}\text { Cumulative } \\
(1977-2000)\end{array}$ & \\
\hline 1 & $\begin{array}{l}\text { High: constant (1976) fuel } \\
\text { prices, no government con- } \\
\text { servation programs }\end{array}$ & 18.3 & 21.0 & 23.6 & 28.1 & 543.6 & 2.3 \\
\hline 2 & $\begin{array}{l}\text { Baseline: Same as } 1 \text { with } \\
\text { rising fuel prices }\end{array}$ & 17.8 & 19.5 & 21.1 & 24.2 & 493.6 & 1.7 \\
\hline \multicolumn{8}{|c|}{ Federal Conservation Programs } \\
\hline 3 & $\begin{array}{l}\text { Baseline plus appliance } \\
\text { efficiency targets }\end{array}$ & 17.5 & 19.0 & 20.5 & 23.6 & 482.3 & 1.5 \\
\hline 4 & $\begin{array}{l}\text { Baseline plus new construction } \\
\text { standards }\end{array}$ & 17.3 & 19.1 & 20.6 & 23.4 & 482.8 & 1.5 \\
\hline 5 & Baseline plus retrofit program & 17.1 & 18.3 & 20.0 & 23.1 & 468.9 & 1.4 \\
\hline 6 & $\begin{array}{l}\text { Baseline plus combined Federal } \\
\text { program }\end{array}$ & 16.7 & 17.5 & 18.9 & 21.6 & 447.2 & 1.2 \\
\hline \multicolumn{8}{|c|}{ Additional Conservation Programs } \\
\hline 7 & $\begin{array}{l}\text { Combined Federal program plus } \\
50 \% \text { fuel price increases }\end{array}$ & 16.7 & 15.2 & 15.4 & 17.0 & 384.2 & 0.2 \\
\hline 8 & $\begin{array}{l}\text { Combined Federal program plus } \\
\text { no market imperfections }\end{array}$ & $16 . ?$ & 17.1 & 18.0 & 19.9 & 428.9 & 0.8 \\
\hline 9 & $\begin{array}{l}\text { Combined Federal program, } 50 \% \\
\text { fuel price increases, no market } \\
\text { imperfections }\end{array}$ & $16 .:$ & 14.9 & 14.8 & 15.8 & 371.4 & -0.1 \\
\hline
\end{tabular}

${ }^{a}$ The model's estimate of residential energy use was 16.3 QBtu in 1976. 
Tajle 2. Alternative residential energy use projections: direct economic effects

\begin{tabular}{|c|c|c|c|c|c|c|}
\hline \multirow{2}{*}{$\begin{array}{l}\text { Run } \\
\text { no. }\end{array}$} & \multirow{2}{*}{ Description } & \multicolumn{4}{|c|}{$\begin{aligned} \text { Present worth of cumulative }(1977-2000) \\
\text { expenditures at } 8 \% \text { real interest rate } \\
\left(10^{9} 1975-\$\right)\end{aligned}$} & \multirow{2}{*}{$\begin{array}{l}\text { Energy-related expenses } \\
\text { in } 2000 \text { as a } \% \text { of } \\
\text { personal income } b\end{array}$} \\
\hline & & Fuels & Equipment $^{a}$ & $\begin{array}{l}\text { thermal } \\
\text { integrity }\end{array}$ & Total & \\
\hline 1 & $\begin{array}{l}\text { High: Constant } 1976 \text { fuel prices, } \\
\text { no government programs }\end{array}$ & 596.2 & 0 & 0 & 596.2 & 2.5 \\
\hline 2 & $\begin{array}{l}\text { Baseline: same as } 1 \text { with rising } \\
\text { fuel prices }\end{array}$ & 659.6 & 2.1 & 1.0 & 662.7 & 3.0 \\
\hline \multicolumn{7}{|c|}{ Federal Conservation Programs } \\
\hline 3 & $\begin{array}{l}\text { Baseline plus appliance effi- } \\
\text { ciency targets }\end{array}$ & 646.3 & 10.7 & 0.7 & 657.7 & 2.9 \\
\hline 4 & $\begin{array}{l}\text { Baseline plus new construction } \\
\text { standards }\end{array}$ & 647.8 & 2.2 & $5 . \mathrm{C}$ & 655.0 & 2.9 \\
\hline 5 & Baseline plus retrofit program & 628.0 & 2.7 & 16.7 & 647.3 & 2.9 \\
\hline 6 & $\begin{array}{l}\text { Baseline plus combined Federal } \\
\text { program }\end{array}$ & 603.4 & 11.2 & 20.7 & 635.3 & 2.7 \\
\hline \multicolumn{7}{|c|}{ Additional Conservation Programs } \\
\hline$?$ & $\begin{array}{l}\text { Combined Federal program plus } \\
50 \% \text { fuel price increases }\end{array}$ & 698.8 & 6.1 & 20.8 & 725.8 & 3.2 \\
\hline 8 & $\begin{array}{l}\text { Combined Federal program plus } \\
\text { no market imperfections }\end{array}$ & 585.8 & 20.0 & 22.9 & 628.7 & 2.6 \\
\hline 9 & $\begin{array}{l}\text { Combined Federal program, } 50 \% \\
\text { fuel price increases, no } \\
\text { market imperfections }\end{array}$ & 680.1 & 15.8 & 23.4 & 719.3 & 3.1 \\
\hline
\end{tabular}


Table 3. Houehold consumption of fuels: 1950-1975

\begin{tabular}{lccccr}
\hline & Electricity & Gas & Oil $^{a}$ & Other $^{b}$ & Total \\
\cline { 2 - 5 } & & \multicolumn{5}{c}{ (QBtu) } \\
\hline 1950 & 1.2 & 1.5 & 1.7 & 2.3 & 6.7 \\
1955 & 1.7 & 2.4 & 2.5 & 1.9 & 8.5 \\
1960 & 2.4 & 3.4 & 2.9 & 1.0 & 9.7 \\
1965 & 3.3 & 4.3 & 3.2 & 1.1 & 11.9 \\
1970 & 5.4 & 5.4 & 3.5 & 1.0 & 15.3 \\
1975 & 7.0 & 5.5 & 3.1 & 0.6 & 16.2 \\
\hline
\end{tabular}

$a_{0 i 1}$ includes kerosine and Nos. 1,2 , and 4 distillate fuel oils; these figures do not include LPG.

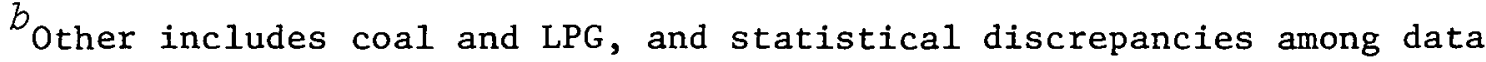
sources (about $2 \%$ of totals).

Sources: refs. 3 and 4 .

fuels (coal, liquified gases) ${ }^{3,4}$ The overall annual growth rate (see Fig. 1) in energy use during this period was $3.6 \%$, nearly double the growth rate in household formation (2.0\%). However, between 1972 and 1975 growth in fuel use was erratic and essentially static.

The distribution of fuels among the total. changed sharply during these 25 years, as shown in Fig. 1. In 1950, coal accounted for more than one-third of household fuel use, while in 1975 coal accounted for only $2 \%$ of the total. Petroleum's share of the total also declined, from $26 \%$ to $19 \%$. Electricity, on the other hand, increased its share from $18 \%$ in 1950 to $43 \%$ in 1975 . The share accounted for by gas increased from $22 \%$ to $34 \%$ during this period.

Figure 2 shows trends in fuel prices from 1950-1975. ${ }^{3}$ Generally, prices were declining or stable until 1970; since then prices for all fuels, especially petroleum products, have risen. The sharp increases 


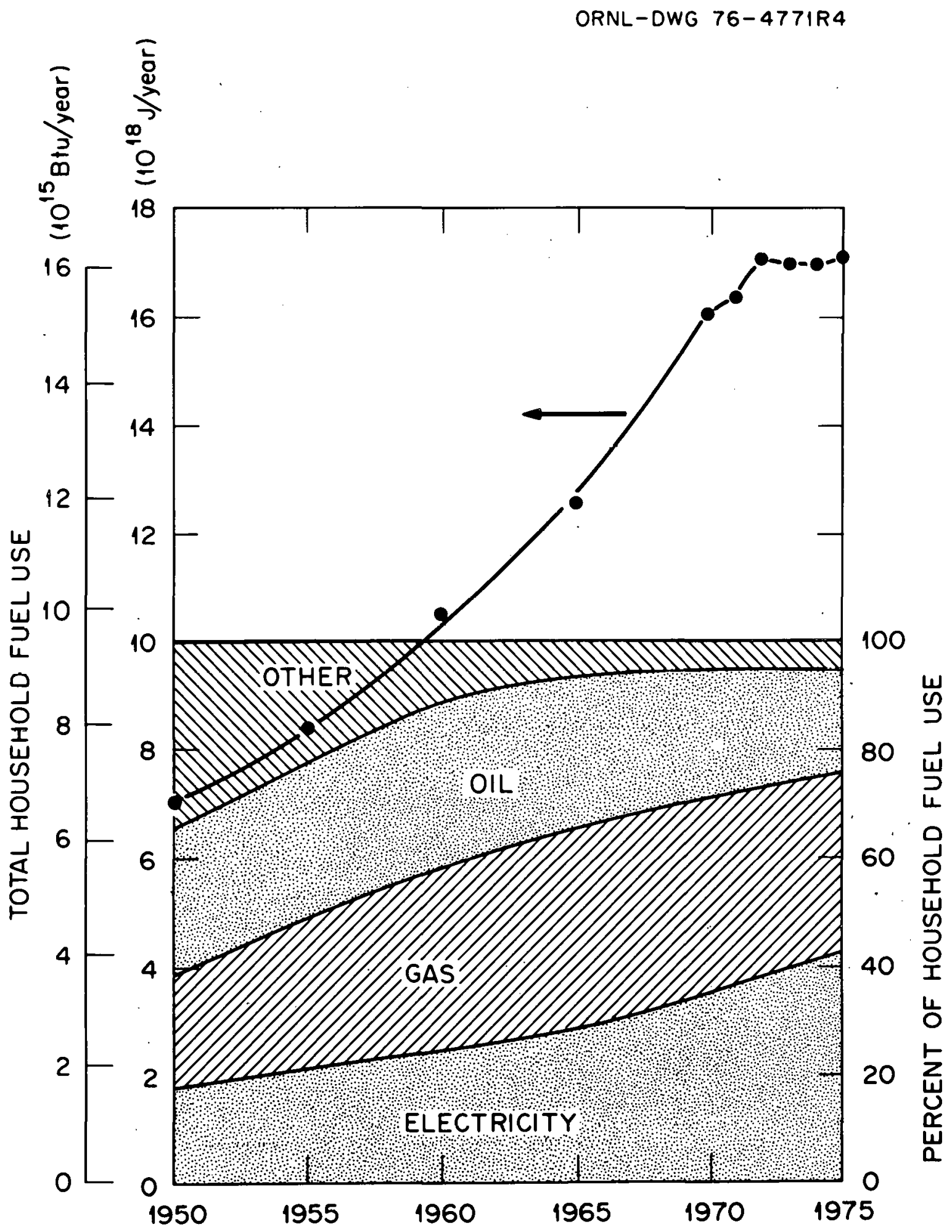

Fig. 1. Household energy use by fuel: 1950-1975. 


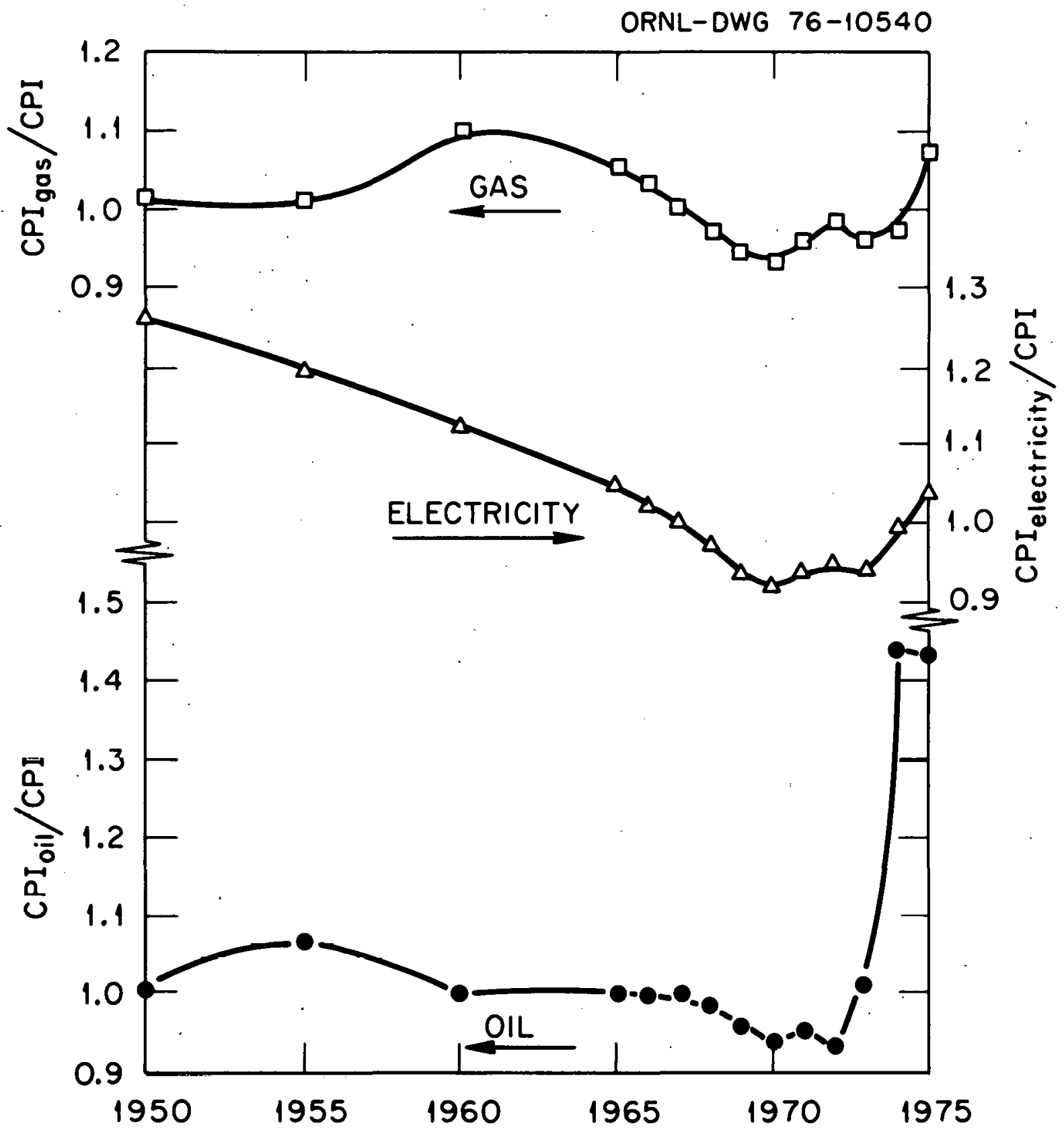

Fig. 2. Trends in retail fuel prices: 1950-1975. Prices are deflated by the Consumer Price Index (CPI) to remove the effects of inflation. 
in fuel prices in the early 1970 s increased dollar expenditures and reduced growth in demand for household fuels. *

Table 4 shows our estimated distribution of residential energy use by fuel and end use for 1975. Space heating is the largest use of fuel in homes, accounting for $53 \%$ of the total. Water heating, the second largest use, accounts for $14 \%$. Thus, these two uses account for twothirds of total household fuel uses. Adding refrigerators, freezers, and air conditioning brings the subtotal to more than $80 \%$. Thus, lighting, cooking, clothes washing and drying, televisions and radios, and operation of small appliances consume less than one-fifth of residential. energy use.

Table 4. Residential energy use by fuel and end use: 1975

\begin{tabular}{|c|c|c|c|c|c|}
\hline & Electricity & Gas & Oil & Other & Tota1 \\
\hline & \multicolumn{5}{|c|}{ (QBtu) } \\
\hline Space heating & 1.36 & 3.81 & 2.88 & 0.54 & 8.59 \\
\hline Water heating & 1.05 & 0.96 & 0.22 & 0.05 & 2.28 \\
\hline Refrigerators & 0.92 & & & & 0.92 \\
\hline Freezers & 0.38 & & & & 0.38 \\
\hline Cooking & 0.46 & 0.29 & & 0.01 & 0.76 \\
\hline Air conditioning & 1.08 & & & & 1.08 \\
\hline Lighting & 0.90 & & & & 0.90 \\
\hline Other & 0.86 & 0.45 & & & 1.31 \\
\hline Tota.1. & 7.01 & 5.51 & 3.10 & 0.60 & 16.22 \\
\hline
\end{tabular}

Sources: refs, $2-4$.

* Real fuel prices in 1976 were higher than in 1975 by the following amounts: electricity $1 \%$, gas $10 \%$, and oil $1 \%$. 
In summary, the 1950-1975 period can be conveniently divided into two time periods: 1950-1972 and 1972-1975. During the first period, energy use grew steadily and rapidly at an average rate of $4.0 \% /$ year while fuel prices either declined smoothly (electricity) or erratically (gas, oil).

Household fuel use grew because of increasing population and households, rising incomes, and declining fuel prices. ${ }^{3}$ Because of these economic and demographic changes there was considerable growth in ownership of energy-intensive household equipment, shifts from small energy-efficient devices to larger less efficient units (e.g., replacement of small manual defrost refrigerators with larger automatic defrost models that consume $50-100 \%$ more electricity), and increasing use of equipment (e.g., taking longer showers, leaving lights on, setting thermostats higher in the winter).

Between 1972 and 1975, residential energy use remained essentially constant while real fuel prices increased sharply: $9 \%$ for electricity, $12 \%$ for gas, and $54 \%$ for oil. During this three year period, per capita income remained nearly constant, compared with an average annual growth of $2.6 \%$ between 1950 and 1972. Similarly, population growth has slowed considerably in recent years. Between 1950 and 1972 population grew at an average annual rate of 1.5\%, while between 1972 and 1975 population grew at $0.8 \% /$ year. Clearly, trends in residential energy use and its determinants have changed during the past few years. 


\section{HIGH ENERGY USE PROJECTION}

In this section we develop a projection of residential energy use to the year 2000 based on assumptions designed to yield a "high" growth in energy use.

Inputs to the ORNL energy use model required to develop a projection include: population, fuel prices, per capita income, and specifications for government conservation programs (e.g., appliance efficiency standards, tax incentives for retrofitting homes, fuel price increases). Each of these inputs must be provided for the 1970-2000 period.

We assume that population grows according to the Bureau of the Census Series II projection. ${ }^{5}$ Per capita income is derived from a recent Data Resources, Inc. projection of Gross National Product (GNP) prepared for $\mathrm{FEA}^{6}$ and the Series II population projection.

Projections of household formation and stocks of occupied housing units are obtained from our housing model ${ }^{2}$ using the DRI per capita income and Census population projections. In developing our estimates of housing stocks, we assume that trends in housing choices (among single-family, multi-family, and mobile homes) between 1960 and 1970 will continue through the end of the century. ${ }^{2}$ Table 5 shows the values of population, households, housing distribution, and per capita income used in all projections discussed in this report.

For the high projection, we assume that real fuel prices remain unchanged between 1976 and 2000 at their 1976 values: ${ }^{*} 2.81 \$ / 10^{6}$ Btu for electric1ty, $1.88 \$ / 10^{6}$ Btu for gas, and $2.83 \$ / 10^{6}$ Btu for o1l.

*All prices and incomes are in terms of constant 1975-\$. Recall that electricity is in terms of primary energy. 
Table 5. Inputs assumed for all projections of residential energy use

\begin{tabular}{|c|c|c|c|c|c|c|}
\hline & \multirow[b]{2}{*}{$\begin{array}{l}\text { Population } \\
\qquad\left(10^{6}\right)\end{array}$} & \multirow[b]{2}{*}{$\begin{array}{l}\text { Households } \\
\left(10^{6}\right)\end{array}$} & \multicolumn{3}{|c|}{$\begin{array}{l}\text { Distribution of occupied } \\
\text { housing units }(\%)\end{array}$} & \multirow{2}{*}{$\begin{array}{c}\text { Per capita } \\
\text { income } \\
(1975-\$)\end{array}$} \\
\hline & & & $\begin{array}{l}\text { single- } \\
\text { family }\end{array}$ & $\begin{array}{l}\text { multi- } \\
\text { family }\end{array}$ & $\begin{array}{l}\text { mobile } \\
\text { home }\end{array}$ & \\
\hline 1970 & 205 & 63 & 69 & 27 & 3 & 5,420 \\
\hline 1975 & 213 & 71 & 67 & 29 & 4 & 5,850 \\
\hline 1976 & 215 & 72 & 67 & 29 & 4 & 6,050 \\
\hline 1980 & 223 & 81 & 65 & 31 & 5 & 7,150 \\
\hline 1985 & 234 & 91 & 63 & 32 & 5 & 7,970 \\
\hline 1990 & 245 & 99 & 62 & 32 & 6 & 8,890 \\
\hline 2000 & 262 & 114 & 61 & 33 & 6 & 10,570 \\
\hline
\end{tabular}

Sources: refs. 2,5 , and 6 .

Finally, we assume that there are no government programs that encourage households to reduce energy use. In other words, we ignore recent legislation (the Energy Policy and Conservation Act ${ }^{7}$ and the Energy Conservation and Production Act $^{8}$ ) and the present administration's proposed programs. (The likely effects of these and other conservation measures will be considered later).

However, the model estimates changes in new equipment and structures efficiencies and changes in usage (i.e., the intensity with which households use existing stocks of equipment) because of the fuel price increases during the early 1970s. Based on information obtained from Owens-Corning Fiberglas (OCF), ${ }^{9}$ we assume that 14.3 million singlefamily and 2.0 million multi-family units will be retrofit during the 1974-1980 period. * We assume that these retrofit actions (e.g.,

* Information obtained from $\mathrm{OCF}^{9}$ suggests that 8.0 million owner-occupied housing units had an average of $4-5$ " of attic insulation added during the 1974-1976 period. 
additional attic insulation, clock thermostat, caulking and weatherstripping, furnace tuneup) will cut space heating energy use $20 \%$ and cost $\$ 225$ for single-family and $\$ 130$ for multi-family units. *

Outputs from the energy model, given these inputs, show residential energy use growing from $16.3 \mathrm{QBtu}$ in 1976 to $18.3 \mathrm{QBtu}$ in $1980,21.0$ in 1985, 23.6 QBtu in 1990, and 28.1 QBtu in 2000. The average growth rate during this 24-year period is $2.3 \%$ /year. Growth in energy use is higher in earlier years and slower in later years.

The contribution of different fuels to the total changes during the projection period. Because of the sharp increase in petroleum prices during the early 1970's and consumer preference for gas and electricity (positive income elasticities for these fuels ${ }^{2}$ ), the fraction of household energy use accounted for by o1: declines from $17 \%$ in 1976 to only $7 \%$ in 2000 . Electricity's share increases from $45 \%$ to $61 \%$ for the reasons given above and also because of growing ownership of electric air conditioners and electric food freezers. The contribution of gas to the total declines from $34 \%$ to $31 \%$ during this period; other fuels also contribute a declining portion of the total, down from $4 \%$ to $1 \%$.

The distribution of energy by end use also changes. Although space heating remains the dominant end use during the rest. of the century, its

\footnotetext{
The Bureau of the Census collected (but did not publish) information on home retrofits as part of the Arriual Housing Survey: 1975. Their data show that occupants of 10.4 million single-family detached housing units took some action in 1975 to weatherize their homes. The average expenditure per household was $\$ 150$. We estimate that these improvements reduced space heating loads by about $6 \%$. The energy saving per $\$$ of investment is lower than our estimate because many households did not invest optimally (i.e., they purchased storm doors and wall insulation rather than attic insulation and caulking/weatherstripping). However, the aggregate energy saving is close to our assumption.
} 
importance declines from 52\% of the total in 1976 to $44 \%$ in 2000 . Air conditioning, on the other hand, increases its share from $7 \%$ to $12 \%$.

Energy use grows more slowly in the high projection than historically for several reasons. First, fuel prices are assumed constant in the projection while historically fuel prices declined. Second, the effects of the fuel price increases in the early 1970s are felt slowly over time and dampen energy growth in the projection period as households replace equipment and structures with systems that are more energy efficient. For example, higher electricity prices increase the percentage of electric space heating systems that is heat pumps from about $15 \%$ during the early 1970 s to about $25 \%$ in the 1980 s and 1990s. A third reason why projected growth is slower than historical relates to "saturation." Between 1950 and 1975, household ownership of air conditioners, refrigerators, freezers, heating systems, and water heating systems increased dramatically. By 1975, almost all households had heating and water heating equipment; more than halt of ail households had air conditioning systems. Thus, the potential for increasing ownership of known energy-using systems is slight. *

\section{BASELINE PROJECTION}

The baseline differs from the high projection only with respect to fuel prices. The exogenous variables listed in Table 5 for the high

\footnotetext{
*our energy model does not explicitly allow for introduction of new end uses (e.g., sidewalk deicing, inside air filtration, swimming pool heating). However, the model does include an "other" end use and this is allowed to grow as incomes rise (depending on growth of fuel prices). In the high projection, energy use for other purposes increases from 1.4 to $2.6 \mathrm{QBtu}$ between 1976 and 2000 .
} 
projection are also used for this projection. However, rather than assume that real fuel prices remain constant at their 1976 levels, we assume that fuel prices increase over time; see Fig. 3.

The fuel price trajectories used as inputs to our model for this and succeeding projections are obtained from the Federal Energy Administration PIES mode1 ${ }^{6}$ and the Brookhaven National Laboratory BESOM model.10 These large energy supply/demand models integrate energy flows from resources in the ground to final demands. As Fig. 3 shows, these projections indicate a substantial increase in real gas prices (average annual growth of $2.3 \%$ between 1976 and 2000) and moderate increases in electricity $(0.9 \% /$ year $)$ and oil ( $1.2 \% /$ year $)$ prices.

In the baseline, residential energy use grows from $16.3 \mathrm{QBtu}$ in. 1976 to 17.8 QBtu in $1980,19.5$ QBtu in $1985,21.1$ QBtu in 1990 , and 24.2 QBtu in 2000 with an average annual growth rate of $1.7 \%$; see Fig. 4. Changes in the distribution of energy use by fuel are similar. to that in the high projection: electricity increases its share of the total and all other fuels decline in importance. Because of rapidly rising gas prices, the share accounted for by gas drops to $24 \%$ in 2000 (compared with $31 \%$ in the high projection); see Fig. 4 . Changes in the distribution of energy by end use are almost the same in the baseline as in the high projection.

The economic penalty associated with rising fuel prices is surprisingly mild. In 1976 , fuel costs amounted to $3.1 \%$ of total personal income. In the baseline, fuel costs amount to $3.0 \%$ of personal income in the year 2000. Thus, even though the average fuel bill per household Increases from $\$ 570$ In 1976 Lo $\$ 730$ in 2000, growlh in pessullal intume more than compensates for fuel cost increases. 


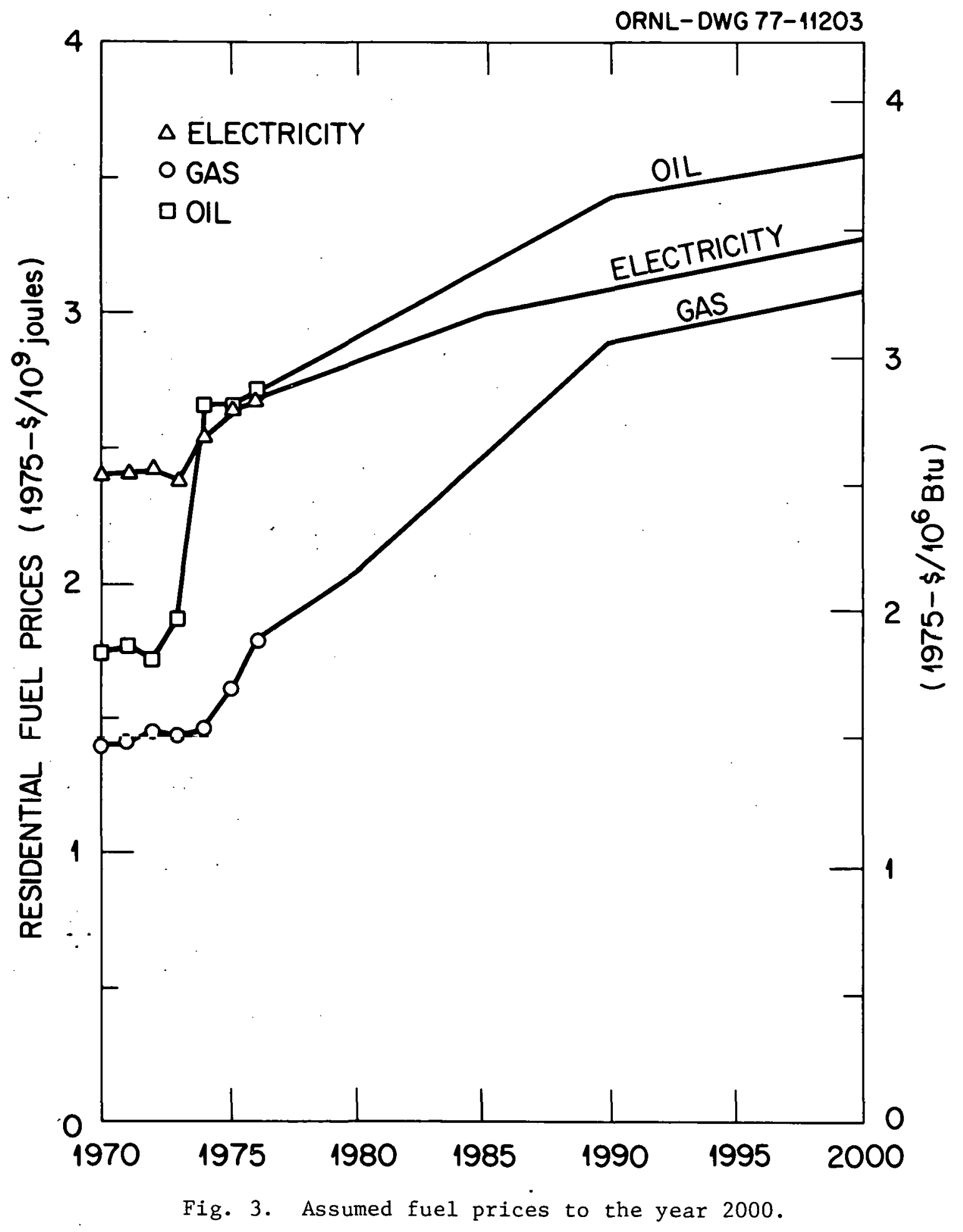




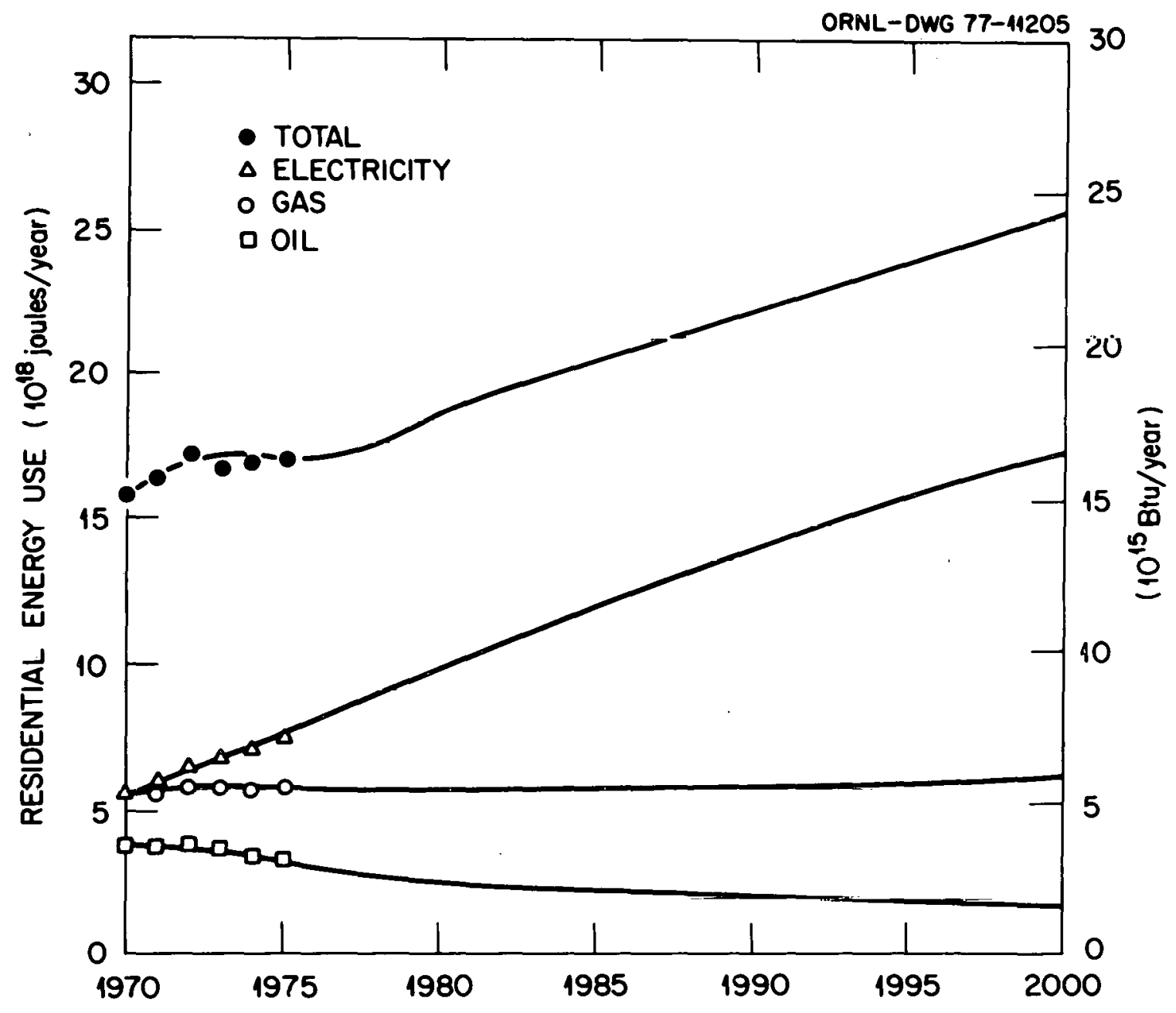

Fig. 4. Baseline projection of residential energy use to the year 2000 . 
The mild economic penalty associated with the increase in average fuel price of almost $40 \%$ between 1976 and 2000 is due primarily to the household voluntary response to price increases. This response takes two forms. In the short-run, households reduce usage of existing stocks of equipment. For example, thermostats are set back during the winter. Thus, in the year 2000, households in the baseline use $10 \%$ less fuel for heating than they do in the high projection.

In the long-run, as existing stocks of equipment and-structures wear out, households replace them with more efficient systems. For example, the average efficiency of new heating equipment in the year 2000 is about $15 \%$ higher in the baseline than in the high projection. Even though fuel prices increase, rising incomes are sufficient to increase household ownership of freezers, air conditioners, lighting fixtures, and "other" uses. Freezer ownership increases from $35 \%$ in 1976 to $49 \%$ in 2000 . Air conditioner ownership increases from $54 \%$ to $89 \%$. The number of lights per household increases $10 \%$ betwecn 1976 and 2000. Ownership of "other" equipment increases $9 \%$.

\section{FEDERAL CONSERVA'IION PROGRAMS}

In this section, we evaluate the energy and economic effects of the residential conservation programs authorized by the 94 th Congress ${ }^{7,8}$ and expanded upon by the present administration. ${ }^{1,6}$ Table 6 summarizes existing authorization and proposals concerning residential energy conservation programs. We evaluate the programs in four elements: 
Table 6. Recent federal legislation and proposals affecting residential energy use

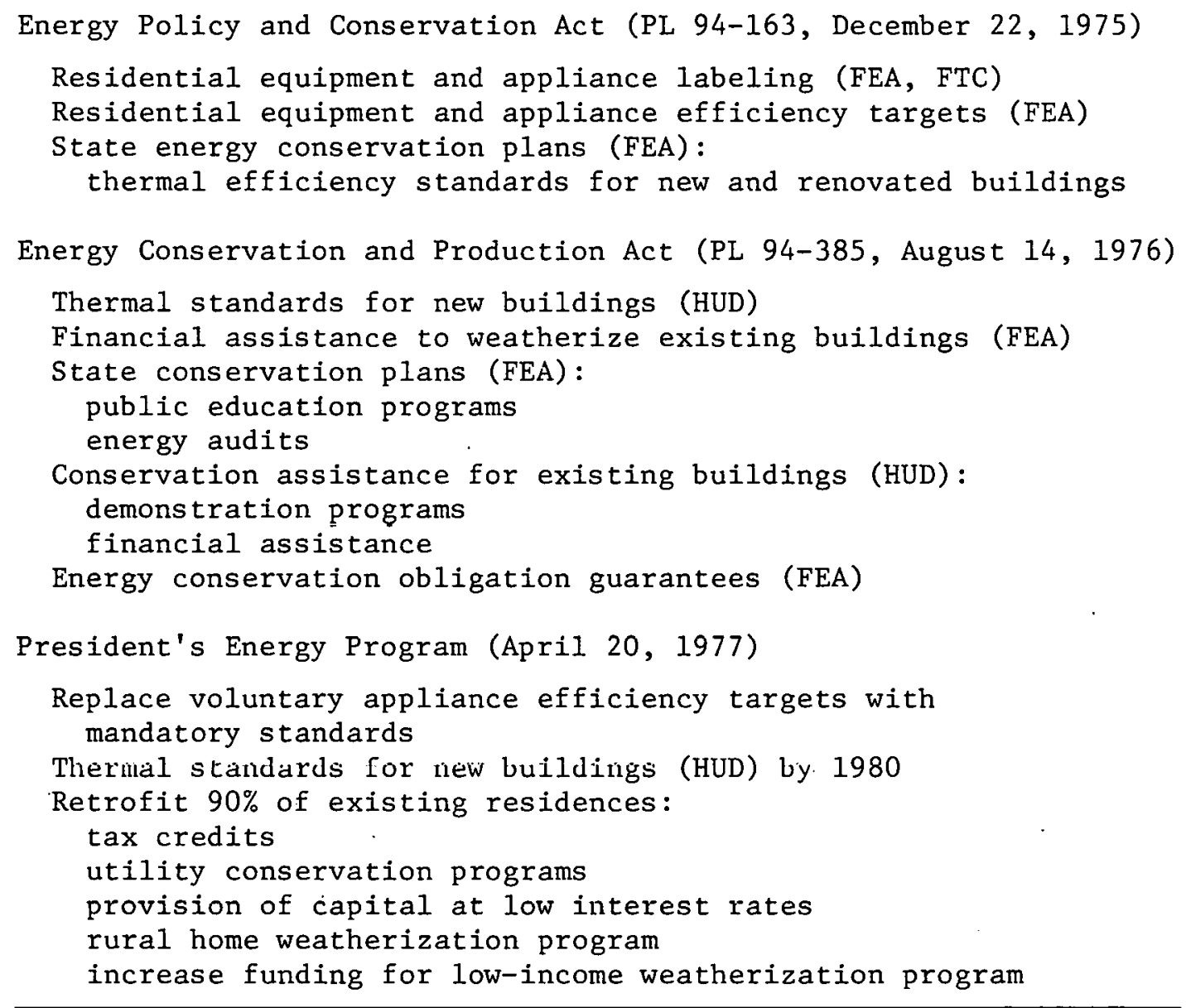

Sources: refs. 1,7 , and 8 .

\section{1. appliance efficiency targets}

2. thermal performance standards for new construction

3. weatherization (retrofit) of existing housing units

4. all of the above.

The time between Congressional authorization and full program implementation can involve several years. The programs discussed here were all authorized by the 94 th Congress; the President has proposed stronger programs in each area. However, none of the programs is yet implemented. 
Each of these programs is compared to the baseline in terms of energy use and household costs. The inputs discussed earlier (Table 5 and Fig. 3) remain unchanged for these runs.

\section{Appliance Efficiency Targets}

The Federal Energy Administration administers the program to develop and implement a set of appliance efficiency targets such that the average efficiency of new appliances sold in 1980 is at least $20 \%$ higher than the 1972 average. ${ }^{7,8}$ The President proposed that the existing voluntary program be made mandatory. ${ }^{l}$ The latest set of FEA targets is shown in Table 7.6

Table 7. Assumed improvements in energy requirements for new equipment from FEA appliance efficiency targets $(1970=1.0)$

\begin{tabular}{ll}
\hline $\begin{array}{l}\text { Space heating } \\
\text { electric }\end{array}$ & 1.0 \\
gas & 0.81 \\
oil & 0.93 \\
Water heating & \\
electric & 0.85 \\
gas & 0.80 \\
oil & 0.81 \\
Refrigerators & 0.68 \\
Freezers & 0.77 \\
A1r cond1tioners & \\
room & 0.65 \\
central & 0.80 \\
Other appliances & \\
electric & 0.90 \\
gas & 0.90 \\
\hline
\end{tabular}

Source: ref. 6 . 
Consider the efficiency targets for water heaters, as an example (Figs. 5 and 6 ). The target calls for a $15 \%$ reduction in energy use for electric water heaters. Our analysis ${ }^{11}$ suggests that this target could be met by replacing existing jacket insulation (2 inches of fiberglass) with 4 inches of urethane foam and adding 1 inch of fiberglass insulation to the distribution line.*

These measures would increase purchase price of the water heater \$42. The reduction in annual fuel bills would be $\$ 36$ (at the 1976 electricity price). The extra cost of the improved electric water heater is repaid in a year.

The target for gas water heaters (20\% reduction in energy use) could be met by replacing the 1 inch of fiberglass insulation on the jacket with 2 inches of urethane foam, adding 1 inch of insulation to the distribution line, and reducing the pilot rate. This would increase the cost of the water heater $\$ 39$. The reduction in annual gas bills would be $\$ 13$. This investment is repaid within three years.

These examples (and our analyses of other appliances) suggest that the FEA appliance efficiency targets provide good investment opportunities for households.

Table 8 summarizes the energy and economic effects of adopting these efficiency targets (Table 7) in 1980. In running this case, the model chooses either the given appliance efficiency target or the voluntary response to fuel price changes, whichever yields more efficient equipment.

\footnotetext{
${ }^{*} 1$ inch $=2.5 \mathrm{~cm}$.
} 


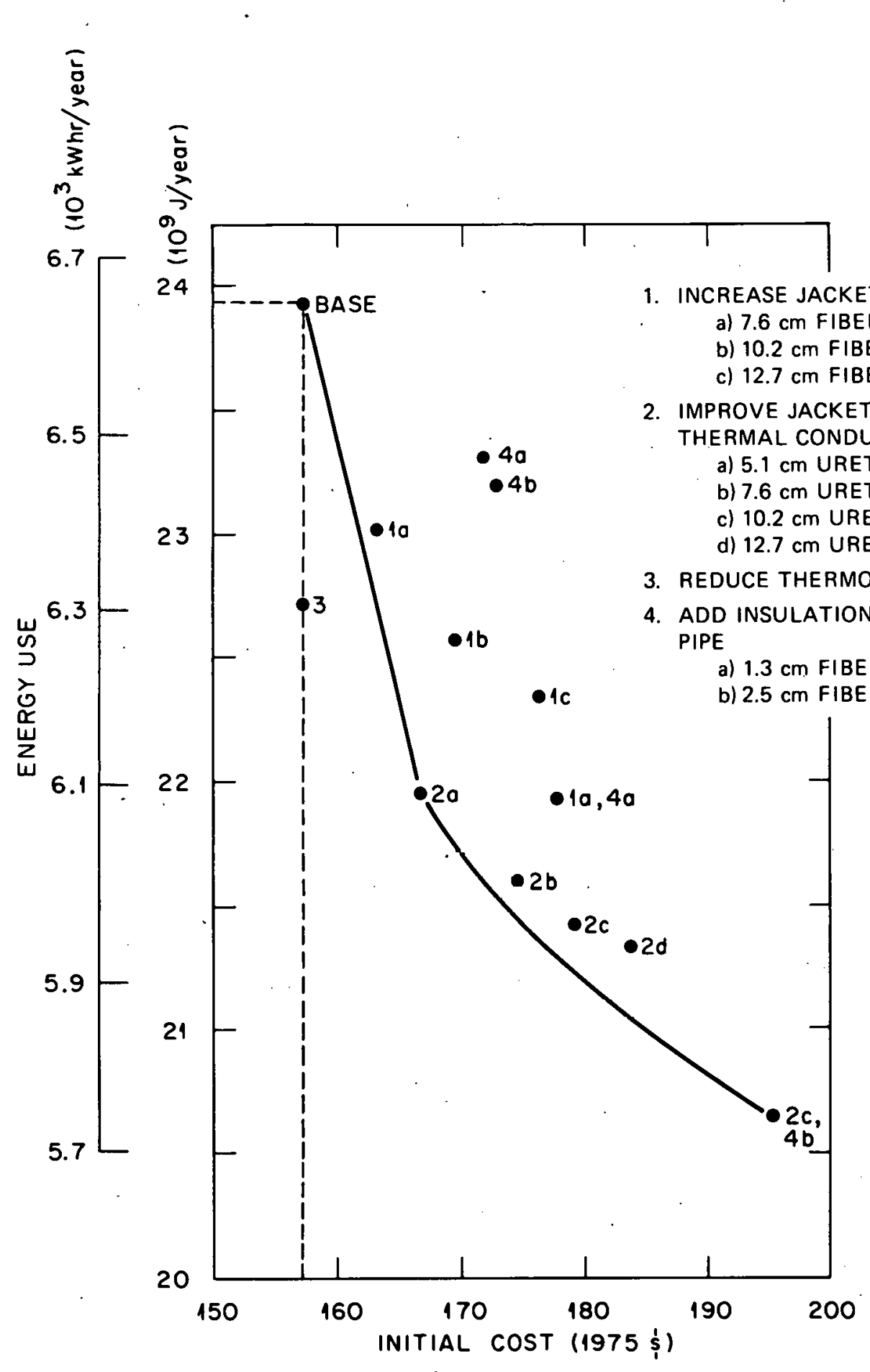

Fig. 5. Energy use versus retail price for a typical electric water heater. 


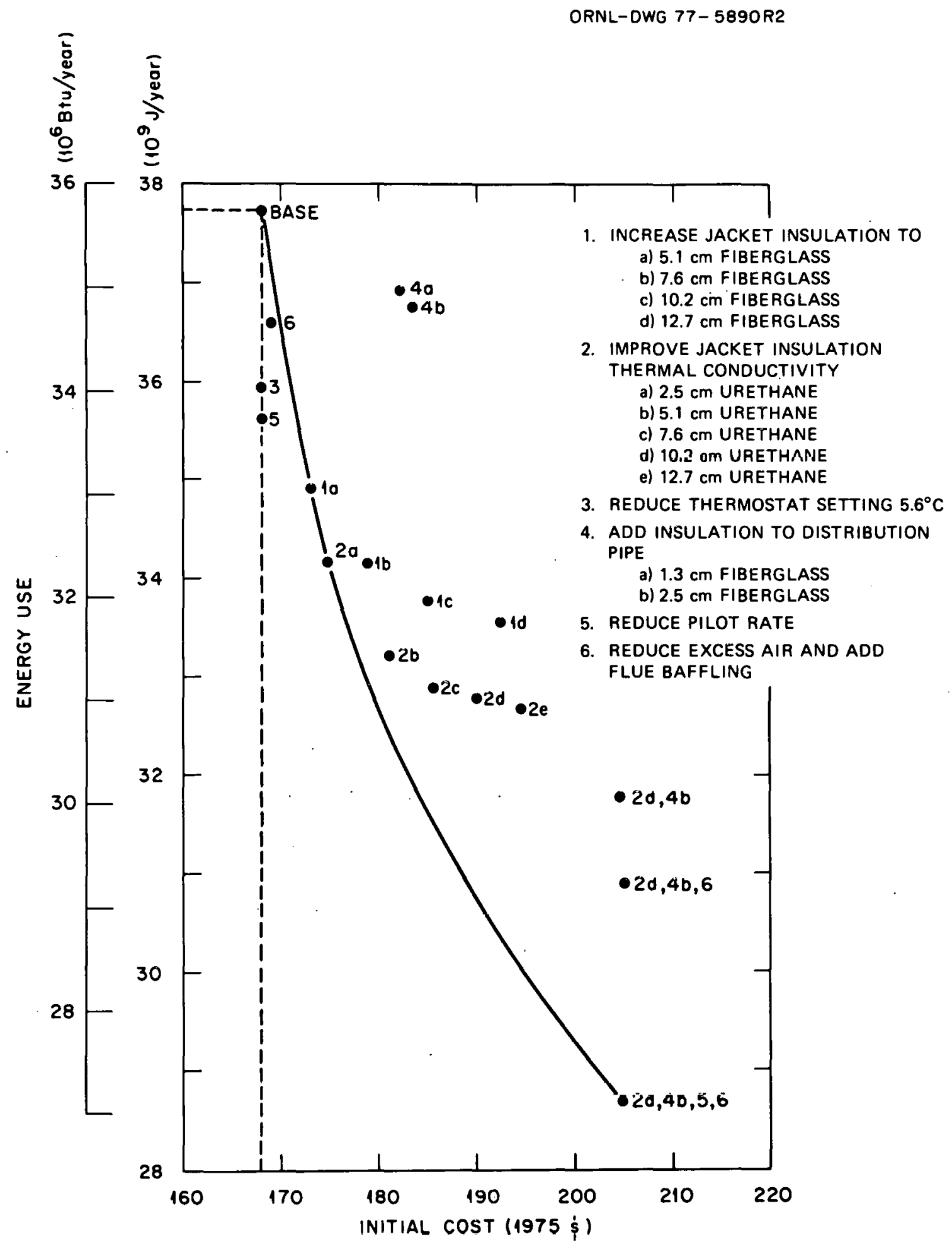

Fig. 6. Energy use versus retail price for a typical gas water heater. 
Table 8. Cumulative (1977-2000) energy and economic effects of appliance efficiency targets $a$

\begin{tabular}{|c|c|c|c|}
\hline Energy benefits & $(\mathrm{QBtu})$ & $\%$ of $t$ & baseline \\
\hline $\begin{array}{l}\text { Electricity } \\
\text { Gas } \\
\text { Oil }\end{array}$ & $\begin{array}{l}9.60 \\
0.99 \\
0.69\end{array}$ & & $\begin{array}{l}3.2 \\
0.7 \\
1.4\end{array}$ \\
\hline Total & 11.28 & & 2.3 \\
\hline \multicolumn{4}{|c|}{$\begin{array}{l}\text { Present worth of economic benefits at } \\
8 \% \text { real interest rate }\left(10^{9} 1975-\$\right)\end{array}$} \\
\hline $\begin{array}{l}\text { Fuels } \\
\text { Equipment } \\
\text { Structures }\end{array}$ & & $\begin{array}{r}13.33 \\
-\quad 8.56 \\
0.24\end{array}$ & \\
\hline Total & & 5.02 & \\
\hline \multicolumn{4}{|c|}{ Benefit $/ \cos t=1.59$} \\
\hline
\end{tabular}

Thus the standards affect equipment choices only when the market-place doesn't.

The energy savings due to improved appliance efficiencies increase from $0.2 \mathrm{QBtu}$ in 1980 to $0.6 \mathrm{QBtu}$ in 1990 and $0.7 \mathrm{QBtu}$ in 2000. The cumulative (1977-2000) energy saving is $11.3 \mathrm{QBtu}, 2 \%$ of the baseline. About $85 \%$ of the energy savings is in electricity; this is because of shifts to electricity for heating and water heating and because the other end uses are powered only by electricity.

The reduction in fuel bills (Table 8) exceeds the increase in capital costs by $\$ 5$ billion. The benefit/cost ratio for the appliance program

\footnotetext{
"Except for space heating, the standards require improvements in equipment efficiency. Voluntary efficiencies are about $15 \%$ higher for oil and $20 \%$ higher for electric heating equipment than required by the standards of Table 7 during the 1990's.
} 
(at the assumed real interest rate of $8 \%$ ) is 1.6 . This suggests that the proposed appliance program would save both energy for the nation and money for households.

\section{New Construction Standards}

The ECPA $^{8}$ requires HUD to develop thermal standards for construction of new buildings within three years (by 1979). These standards must then be implemented by the states, but only if Congress takes affirmative action. The President's energy program proposed to "advance by one year, from 1981 to 1980 , the effective date of the mandatory standards required for new residential and commercial buildings."1 Table 9 summarizes the likely improvements in space heating and air conditioning loads because of these standards.12 These standards provide larger percentage savings in multi-family units than in single-family units. This is consistent with the changes likely from implementing the ASHRAE 90-75 standards or the June 1976 HUD standards.13 We also assume that all mobile homes constructed between 1976 and 2000 meet the recent HUD standards. 14

The incremental capital cost of constructing a gas-heated singlefamily home in accordance with the standards shown in Table 9 is about $\$ 500 ;^{2}$ see Fig. $7 .^{*}$ This includes labor and materials costs for additional insulation, storm doors, and storm windows; minus savings for smaller heating and air conditioning equipment. The reduction in annual heating

\footnotetext{
* The relationship between annual heating load and capital cost shown in Fig. 7 is for a 1,500 $\mathrm{ft}^{2}$ single-family house located in New York City, for which the annual heating legree day measure is close to the national average.
} 


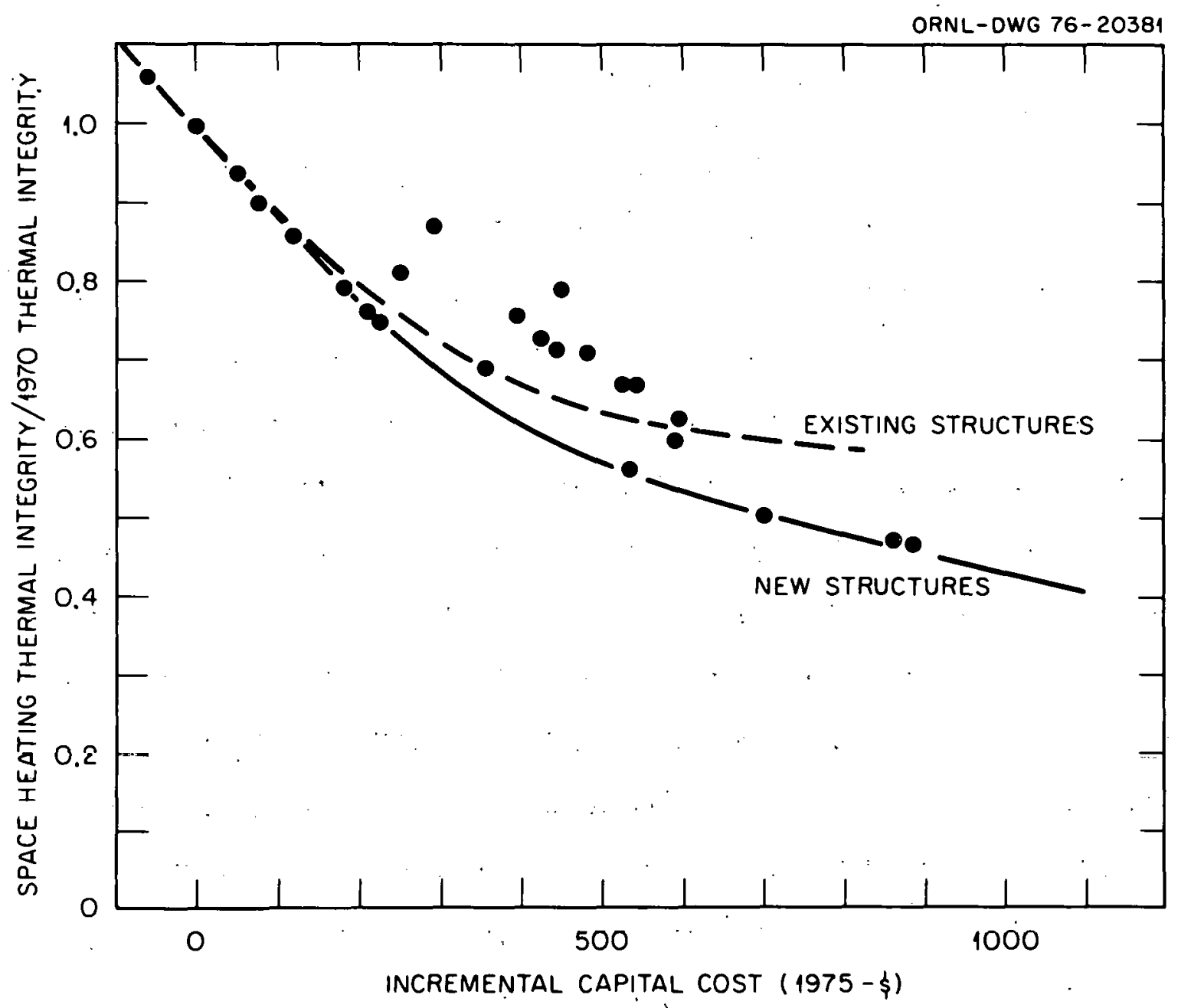

Fig. 7. Space heating thermal integrity for single-family units versus increased capital costs. 
Table 9. Assumed improvements in thermal integrities for residential structures $(1970=1.0)$

\begin{tabular}{lccc}
\hline & 1980 HUD & Retrofit actions ${ }^{a}$ \\
\cline { 2 - 4 } & & Voluntary & Federal \\
\hline $\begin{array}{l}\text { Single-family units } \\
\text { space heating }\end{array}$ & $0.70 / 0.60$ & 0.80 & 0.65 \\
air conditioning & 0.71 & 0.84 & 0.70 \\
Multi-family units & & 0.80 & 0.72 \\
space heating \\
air conditioning
\end{tabular}

bills would be $\$ 90$ (at the 1976 gas price) and the reduction in annual cooling bills would be $\$ 35$. Thus, investment in tighter building construction pays back in four years.

Table 10 summarizes the energy and economic effects of implementing the new construction standards of Table 9. The energy savings increase from 0.1 QBtu in 1980 to $0.5 \mathrm{QBtu}$ in 1990 and $0.8 \mathrm{QBtu}$ in 2000. The cumulative energy savings total $10.8 \mathrm{QBtu}$, almost as much as the savings due to the appliance efficiency program.

About $67 \%$ of the cumulative energy savings is electricity, $21 \%$ gas, and the remainder oil. Electricity accounts for so much of the savings 
Table 10. Cumulative (1977-2000) energy and economic effects of new construction standards $\alpha$

\begin{tabular}{|c|c|c|c|}
\hline Energy benefits & $(\mathrm{QBtu})$ & $\%$ of & baseline \\
\hline $\begin{array}{l}\text { Electricity } \\
\text { Gas } \\
\text { Oil }\end{array}$ & $\begin{array}{l}7.26 \\
2.27 \\
1.22\end{array}$ & & $\begin{array}{l}2.4 \\
1.7 \\
2.5\end{array}$ \\
\hline Total & 10.76 & & 2.2 \\
\hline \multicolumn{4}{|c|}{$\begin{array}{l}\text { Present worth of economic benefits at } \\
8 \% \text { real interest rate }\left(10^{9} 1975-\$\right)\end{array}$} \\
\hline $\begin{array}{l}\text { Fuels } \\
\text { Equipment } \\
\text { Structures }\end{array}$ & & $\begin{array}{r}11.78 \\
-\quad 0.05 \\
-4.06\end{array}$ & \\
\hline Total & & 7.68 & \\
\hline \multicolumn{4}{|c|}{ Benefit $/ \cos t=2.87$} \\
\hline
\end{tabular}

because all air conditioning savings are electricity and because more than $40 \%$ of new housing units are heated with electricity.

The economic benefits of the new construction standards are $50 \%$ larger than those for the appliance efficiency targets. Fuel bill reductions exceed additional construction costs by almost $\$ 8$ billion. The benefit/cost ratio for these standards is 2.9 .

\section{Retrofit Program}

A number of provisions in $\mathrm{EPCA}^{7}$ and $\mathrm{ECPA}^{8}$ encourage weatherization of existing structures. For example, ECPA authorizes FEA to provide financial assistance to low-income households to weatherize their structures; and authorizes HUD to conduct demonstration programs to provide 
financial assistance for improving the energy performance of existing buildings. The April 1977 energy message ${ }^{l}$ proposes a number of measures to meet the goal of "insulating $90 \%$ of all residences." These measures include tax credits for retrofits, requirements that electric and gas utilities assist their customers in weatherizing structures, increased funding for the low-income weatherization program, and implementation of a rural home weatherization program.

Based on conversations with FEA staff, 12 we assume the parameters for the retrofit program shown in Table 9. The retrofit costs per housing unit are $\$ 580$ for single-family and $\$ 240$ for multi-family units. These reductions in heating and cooling demands are assumed to be implemented in 42 million single-family homes and 7 million multi-family homes by 1985 .

Table 11 summarizes the energy and economic effects of retrofitting these housing units. The energy savings increase from $0.7 \mathrm{QBtu}$ in 1980 to 1.2 QBtu in 1985; the savings then decline slowly through the end of the century (1.1 QBtu in 2000). The cumulative savings of $25 \mathrm{QBtu}$ is double the savings from either the appliance efficiency targets or the new construction standards. The retrofit savings are large both because so many housing units are affected and because the assumed improvements are large.

The economics of the retrofit program are quite attractive. Reduc'tions in fuel bills exceed increased capital costs by $\$ 15$ b1111on. The benefit/cost ratio for this program is 1.9 . 
Table 11. Cumulative (1977-2000) energy and economic effects of retrofit program ${ }^{a}$

\begin{tabular}{|c|c|c|c|}
\hline Energy benefits & (QBtu) & $\%$ of & baseline \\
\hline $\begin{array}{l}\text { Electricity } \\
\text { Gas } \\
\text { Oil }\end{array}$ & $\begin{array}{r}15.81 \\
6.36 \\
2.49\end{array}$ & & $\begin{array}{l}5.2 \\
4.8 \\
5.2\end{array}$ \\
\hline Total & 24.66 & & 5.0 \\
\hline \multicolumn{4}{|c|}{$\begin{array}{l}\text { Present worth of economic benefits at } \\
8 \% \text { real interest rate }\left(10^{9} 1975-\$\right)\end{array}$} \\
\hline $\begin{array}{l}\text { Fuels } \\
\text { Equipment } \\
\text { Structures }\end{array}$ & & $\begin{array}{r}31.65 \\
-0.56 \\
-15.74\end{array}$ & \\
\hline Total & & 15.36 & \\
\hline \multicolumn{4}{|c|}{ Benefit/cost $=1.94$} \\
\hline
\end{tabular}

\section{Combined Federal Program}

Table 12 summarizes the energy and economic benefits of adnpting a11 three of the programs discussed above; see also Figs. 8 and 9 . The energy savings increase from 1.1 QBtu in 1980 to 2.2 QBtu in 1990 and 2.6 QBtu in 2000. The cumulative saving of $46 \mathrm{QBtu}$ is $9 \%$ of the baseline. Energy. growth between 1976 and 2000 is reduced from 1.7 to $1.2 \% / y r$.

The combined program reduces energy-related costs to consumers by $\$ 27$ billion. The overall benefit/cost ratio for the program is 2.0 . Energy-related expenditures are reduced with the combined program from $3.0 \%$ to $2.7 \%$ of personal income in the year 2000. Figure 9 shows that the incremental capital costs of improved equipment and structures exceed fuel bill reduction until 1982. After 1982, however, the annual fuel bill reductions exceed extra capital costs. 


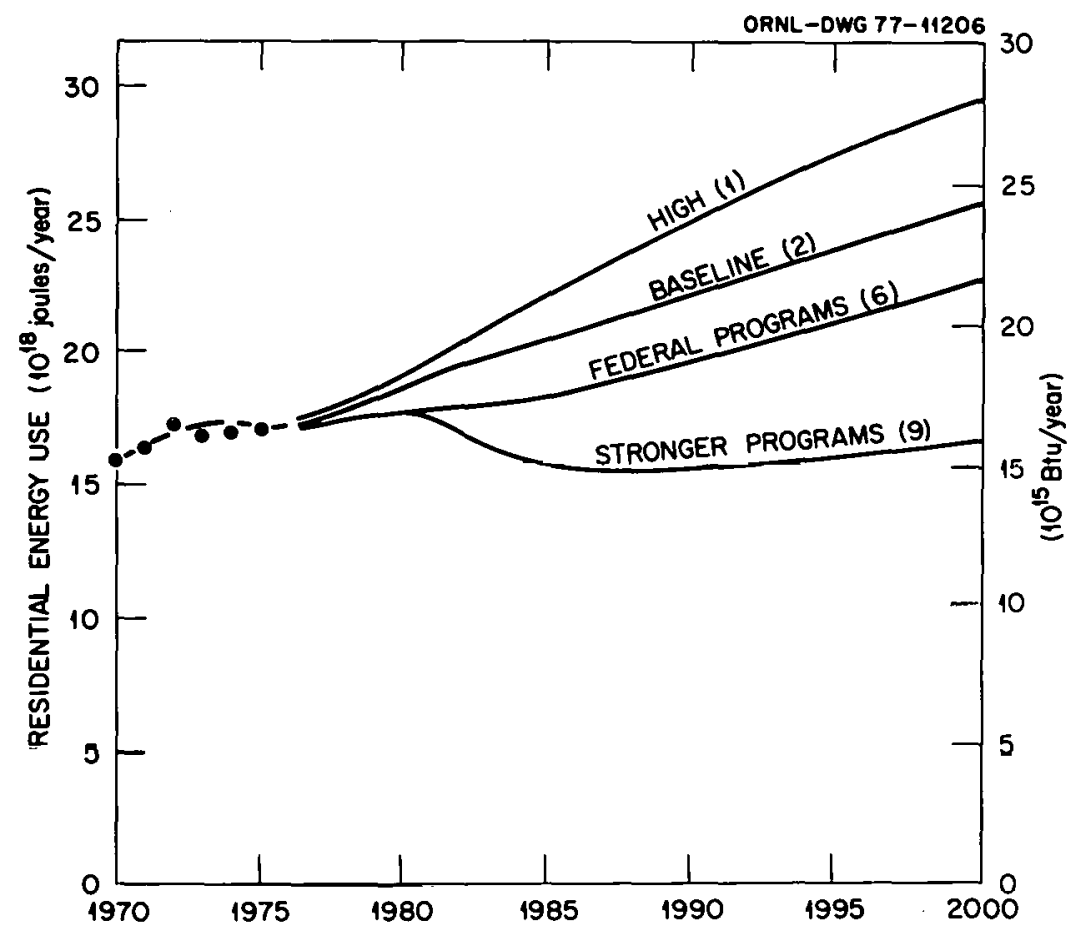

Fig. 8. Alternative projections of residential energy use to the year 2000 .

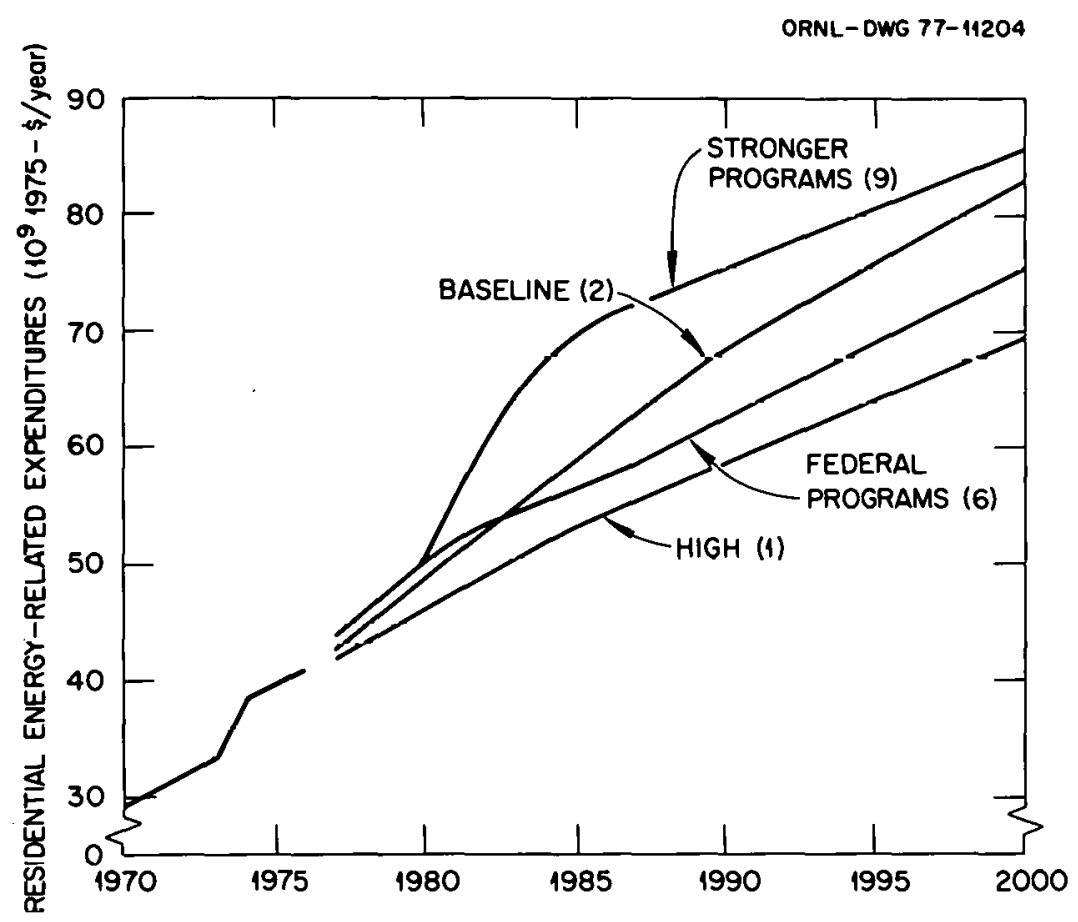

Fig. 9. Alternative projections of residential energy-related expenditures to the year 2000 . 
Table 12. Cumulative (1977-2000) energy and economic effects of combined Federal program ${ }^{a}$

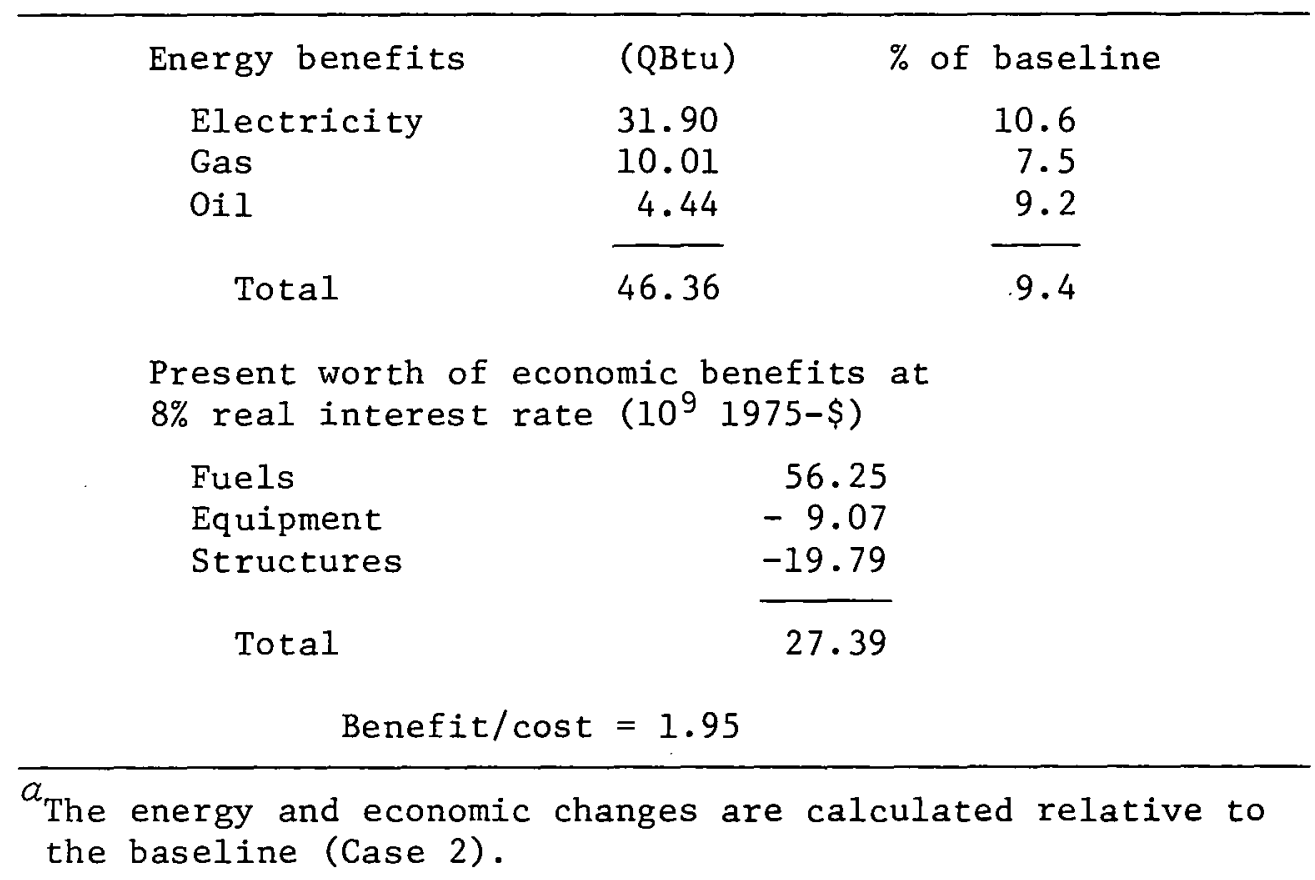

The lifestyle changes implied by the federal programs are minor and all positive. The reduced operating costs implied by the programs increase the intensity with which households are expected to operate their equipment and slightly increase ownership of energy-using equipment. For example, $89 \%$ of the households in 2000 own air conditioning systems in the baseline compared to $91 \%$ with the combined federal program. Similarly, ownership of freezers is increased in 2000 from $49 \%$ to $50 \%$.

The model results suggest that households will use their space heating systems in the year 2000 15\% less frugally with the combined program than in the baseline. Households respond to fuel bill reduction induced by improved equipment efficiencies and tighter construction by raising winter thermostats and paying less attention to door and window openings. Similarly, water heating systems are used $8 \%$ more intensively in 2000 with the federal program than without. 


\section{ADDITIONAL PROGRAMS}

The results in section 5 suggest that the conservation programs proposed and planned by the federal government are likely to save large amounts of energy (46 QBtu) and money ( $\$ 27$ billion). However, the question remains: What effects would stronger programs have on energy use and household economics? This section examines two additional conservation programs.

The first involves large increases in fuel prices. Case 7 is the same as Case 6 (combined federal program) except that fuel prices are increased by $10 \%$ in $1981,20 \%$ in 1982 , and so on until fuel prices are higher by $50 \%$ for the years $1985-2000$. Such fuel price increases might occur because of increasingly strict environmental standards (e.g., sulfur removal from power plants, strip mine reclamation, increased costs for nuclear fuel reprocessing and storage), because of increasing scarcity of gas and oil and the consequent higher costs of extraction (and the higher opportunity costs for these fuels), and because of the social costs associated with large energy production facilities. Alternatively, governments might choose to tax fuels.*

The second program involves greater efficiency improvements in new equipment and structures than those shown in Tables 7 and 9 . The Federal government's proposed standards reduce lifecycle costs to consumers but

\footnotetext{
*The National Energy Planl proposes to price fuels at their "replacement cost" so that fuel prices reflect the costs of providing additional units of that fuel. Under this proposal natural gas, for example, might be priced at the cost of importing liquified natural gas or at the cost of producing synthetic gas from coal.
} 
they do not minimize lifecycle costs. In Case 8 , the model selects the "optimal" (in the sense of minimum lifecycle costs at consumers' implicit rates of return; see Appendix Tables A-1 and A-2) combination of equipment and structures beginning in 1980. Such changes could come about through stronger government regulatory programs. Or such changes might occur through increased awareness and motivation on the part of consumers. At the present time, it is difficult for consumers to collect and process information they need to make "rational" decisions concerning equipment and structures efficiency. However, government education programs, energy efficiency labels, and other information programs could provide that data and thereby encourage consumers to choose more efficient equipment and structures.

\section{Higher Fue1 Prices}

Increasing the fuel prices shown in Fig. 3 reduces energy use by 2.3 QBtu in 1985, 3.5 QBtu in 1990, and 4.6 QBtu in 2000 relative to the future with the combined federal program (Case 6). Growth in energy use is cut from $1.2 \%$ to $0.2 \% /$ year. Clearly, increasing fuel prices produces dramatic effects on energy use; see Table 13.

These higher fuel prices increase consumer expenditures on fuels and also on efficient equipment and structures. Energy-related expenditures in the year 2000 amount to $3.2 \%$ of personal income, compared with $3.0 \%$ in the baseline and $2.7 \%$ with the federal program. The cumulative increase in expenditures (at $8 \%$ ) is $\$ 90$ billion relative to the case with the federal program, $\$ 63$ billion compared with the baseline. Although 
Table 13. Cumulative (1977-2000) energy and economic effects of increased fuel prices and combined Federal program ${ }^{a}$

\begin{tabular}{|c|c|c|c|}
\hline Energy benefits & (QBtu) & $\%$ of & baseline \\
\hline $\begin{array}{l}\text { Electricity } \\
\text { Gas } \\
\text { Oil }\end{array}$ & $\begin{array}{l}69.83 \\
28.91 \\
10.58\end{array}$ & & $\begin{array}{l}23.1 \\
21.6 \\
21.9\end{array}$ \\
\hline Total & 109.33 & & 22.2 \\
\hline \multicolumn{4}{|c|}{$\begin{array}{l}\text { Present worth of economic benefits at } \\
8 \% \text { real interest rate }\left(10^{9} 1975-\$\right)\end{array}$} \\
\hline $\begin{array}{l}\text { Fuels } \\
\text { Equipment } \\
\text { Structures }\end{array}$ & & $\begin{array}{l}-39.23 \\
-\quad 3.99 \\
-19.86\end{array}$ & \\
\hline Total & & -63.07 & \\
\hline
\end{tabular}

the relative economic costs of the increased fuel prices are small compared with personal income, the absolute costs are large.*

It is also interesting to examine the lifestyle changes implied by these large price increases. Surprisingly, the effects on ownership of air conditioners and food freezers (the only end uses that are not already saturated) are almost negligible. In the baseline, $49 \%$ of the households own food freezers in 2000; in the high price case, $47 \%$ own freezers. Air conditioner ownership is essentially unchanged. However, the number of lighting fixtures and ownership of other appliances are reduced $30 \%$ in the year 2000 relative to the baseline.

\footnotetext{
* If the additional fuel expenditures are returned to consumers through tax rebates, there will be no economic cost of the higher fuel prices. There will, however, be an income transfer from households that use large amounts of finel to those that use small amounts.
} 
Changes in usage are significant. Higher fuel prices cut usage for space heating by $10-15 \%$ and water heating by $15-20 \%$ in 2000 . This suggests that higher fuel prices induce households to lower thermostat settings in the winter and to use less hot water than they would at lower fuel prices. However, these do not constitute major lifestyle changes. For example, space heating energy use can be cut $15 \%$ by lowering thermostat settings $5^{\circ} \mathrm{F}$. A $10 \%$ reduction in hot water use plus a reduction in water temperature of $10^{\circ} \mathrm{F}$ would cut water heater energy use $15 \%$.

\section{Elimination of Market Imperfections}

Here we allow the model to select the mix of equipment and structures that minimizes lifecycle costs to consumers beginning in 1980 .* Fuel prices and other exogenous variables are the same as for the combilled federal proyrall.

Relative to the case with Federal programs, energy savings increase from 0.4 QBtu in 1985 to 0.9 QBtu in 1990 and $1.8 \mathrm{QBtu}$ in 2000. The average growth in energy use is cut from 1.2 to $0.8 \% / y e a r$. The energy benefits of eliminating market imperfections after 1980 are much greater when compared with the baseline case; see Table 14.

The economic benefits of either forcing or encouraging consumers to make purchase decisions at their implicit interest rates are significant.

\footnotetext{
Although the markets that determine equipment and structures efficiencies are assumed to operate perfectly in this case, the solution may still not be socially-optimal. This is because the fuel prices used here may not reflect the full marginal social cost of these resources (see discussion of preceding case).
} 
Table 14. Cumulative (1977-2000) energy and economic effects of elimination of market imperfections and combined Federal program ${ }^{a}$

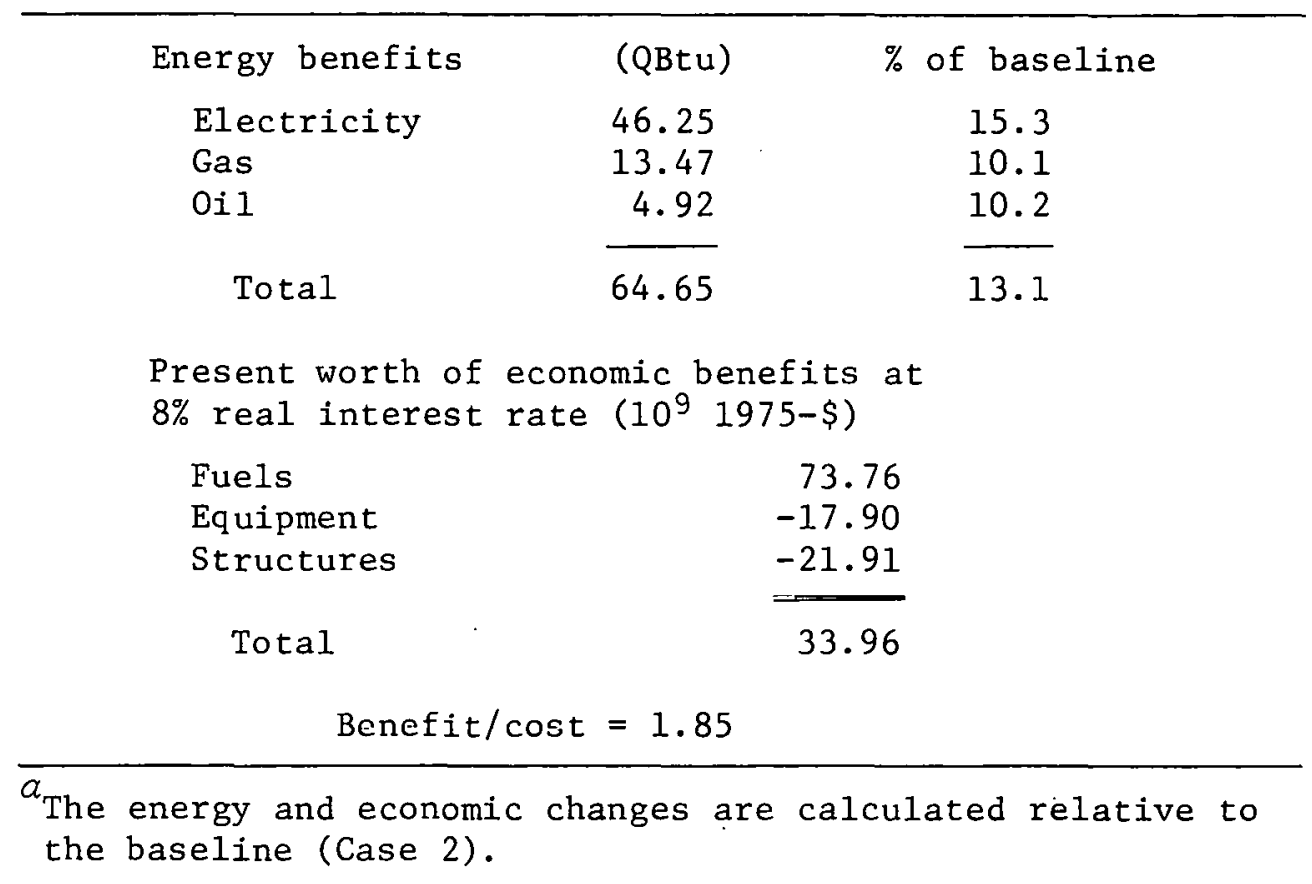

Table 14 shows that the reduction in fuel bills relative to the baseline exceeds the increase in capital costs by $\$ 34$ billion.

Comparing Tables 13 and 14 shows that the energy benefits of fuel price increases are about double those from elimination of market imperfections. However, the economic cost of fuel price increases is $\$ 90$ billion higher.

\section{Higher Fuel Prices and Elimination of Market Imperfections}

Here we combine the two preceding changes; see Table 15. Energy use drops $10 \%$ between 1980 and 1985 and then increases slowly to the end of the century. Energy use in the year 2000 is $3 \%$ less than it was in the year 1976. Thus, this case yields zero energy growth in the residential sector; see Fig. 8 . 
Table 15. Cumulative (1977-2000) energy and economic effects of increased fuel prices, elimination of market imperfections, and combined Federal program $a$

\begin{tabular}{lrc}
\hline Energy benefits & (QBtu) & \% of baseline \\
Electricity & 80.10 & 26.5 \\
Gas & 31.11 & 23.2 \\
Oil & 10.99 & 22.8 \\
Total & 122.21 & 24.8 \\
Present worth of economic benefits at \\
8\% real interest rate (109 1975-\$) \\
Fuels \\
Equipment \\
Structures \\
Total & -20.54 \\
& -13.62 \\
The energy and economic changes are calculated relative to \\
the baseline (Case 2).
\end{tabular}

Energy-related household expenses in the year 2000 total \$86 billion, compared with $\$ 75$ billion with federal programs and $\$ 83$ billion in the baoclinc; see Fig. 9 . As a pus llul ul personal incomèe, energy-related costs amount to $3.1 \%$ in 2000 , compared with $2.7 \%$ with federal programs and $3.0 \%$ in the baseline. The cumulative increase in energy-related costs amounts to $\$ 57$ billion compared with the baseline.

\section{SUMMARY}

We used a detailed engineering-economic simulation model of residential energy use to evaluate the effects of nine different residential energy use futures. These futures are described in terms of annual and cumulative (1977-2000) energy use by fuel, end use, and in aggregate. Outputs from the model also include economic information on the costs to 
households of fuels, equipment, and thermal improvements to new and existing structures. The major outputs from these nine cases are shown in Tables 1 and 2 and Figs. 7 and 8 .

Our conclusions and interpretations of these runs are:

1. Residential energy use will almost surely grow more slowly during the remainder of this century than it did in the past. Energy use grows at $2.3 \%$ year in our high case, compared with an average growth of $4.0 \% /$ year between 1950 and 1972. If residential energy use grew at 4.0\%/year from 1976 through 2000, it would.reach 42 QBtu in 2000 - almost $50 \%$ higher than the estimate from our high projection.

This significant reduction in energy growth is due to the long-run effects of fuel price increases from 1972 through 1976, reductions in population growth, absence of new energy-intensive household functions, and near-saturation of existing household functions.

2. Our high projection assumes that real fuel prices remain constant between $1976^{\circ}$ and 2000 . However, all projections we have seen show increases in fuel prices to the year 2000. In our baseline projection, we use fuel prices from FEA and ERDA (Fig. 3) that are roughly $40 \%$ higher in 2000 than in 1976.

The effect of these price increases is to cut energy use $14 \%$ in the year 2000. Cumulative energy use in the baseline is $9 \%$ less than in the high projection. The baseline projection assumes no government programs. Changes in equipment and structure energy efficiencies and changes in household behavior occur only because of voluntary responses to fuel price changes. Thus, the "business as usıa.1." response to the assumed higher fuel prices is to cut energy growth to $1.7 \% /$ year; energy 
use in the year 2000 is only about half of what it would be if historical trends ( $4.0 \% /$ year) continued through the end of the century.

3. Implementation of conservation programs that encourage or force manufacturers to produce and consumers to purchase more efficient equipment and structures saves energy and money. These programs - appliance efficiency standards, thermal performance standards for new construction, and a program to retrofit existing housing units - reduce energy growth from $1.7 \%$ year (baseline) to $1.2 \%$ /year. The cumulative energy savings total 46 QBtu (69\% electricity, $22 \%$ gas, $9 \%$ oil).

In addition, these programs reduce lifecycle costs to consumers of owning and operating households. The present worth of the net benefits (at $8 \%$ ) amounts to $\$ 27$ billion.

Of the three programs, retrofitting existing homes provides the largest energy and economic benefits. This is because we assume that al1 the retrofits are accomplished by 1984; most of these housing units rellain in the stock through the year 2000. However, many of the new units affected by the HUD standards are not built until the 1990s; they provide much smaller cumulative energy savings.

The energy savings due to the appliance program would be larger if standards for electric space heating systems were imposed. In the 1980s and 1990s, about $35 \%$ of all new heating systems are electric. Standards that increased the efficiency of these new electric heating systems $5 \%$ would increase the appliance program energy savings almost $50 \%$ in the year 2000. Significant improvements in efficiencies of electric systems are possible through use of electric heat pumps. Presently available heat pumps require about $55 \%$ as much electricity for heating as do 
resistance heating systems; advanced heat pumps might require only $40 \%$ as much electricity.

4. Because the federal programs examined here offer benefits to society in terms of reduced energy consumption and benefits to households in terms of reduced costs and less frugal usage patterns, we examined the potential for stronger conservation programs. Specifically, we evaluated the effects of large fuel price increases and elimination of market imperfections concerning production and consumption of residential appliances, equipment, and structures after 1980. The model results show that zero energy growth in the residential sector can be achieved with higher fuel prices. However, these fuel price increases raise costs to consumers. For example, our last case shows an increase in the year 2000 energy-related expenditures from $3.0 \%$ in the baseline to $3.1 \%$ of personal income. The cumulative direct cost to consumers of higher fuel prices is $\$ 63$ billion.

Table 16 summarizes the energy and economic effects of each of the five programs considered here. Fuel price increases offer the largest energy benefit; unfortunately they also increase costs to consumers. The retrofit program offers the second largest energy savings and the largest economic benefit. In fact, all the programs (except for fuel price increases) save both energy and money. Combining all the programs except fuel price increases cuts energy growth to $0.8 \%$ /year, to 19.9 QBtu in 2000. The economic benefits of this program total $\$ 34$ billion. This suggests that enormous energy savings are possible, savings that also provide large economic benefits to households. 
Table 16. Effects of residential energy conservation measures ${ }^{a}$

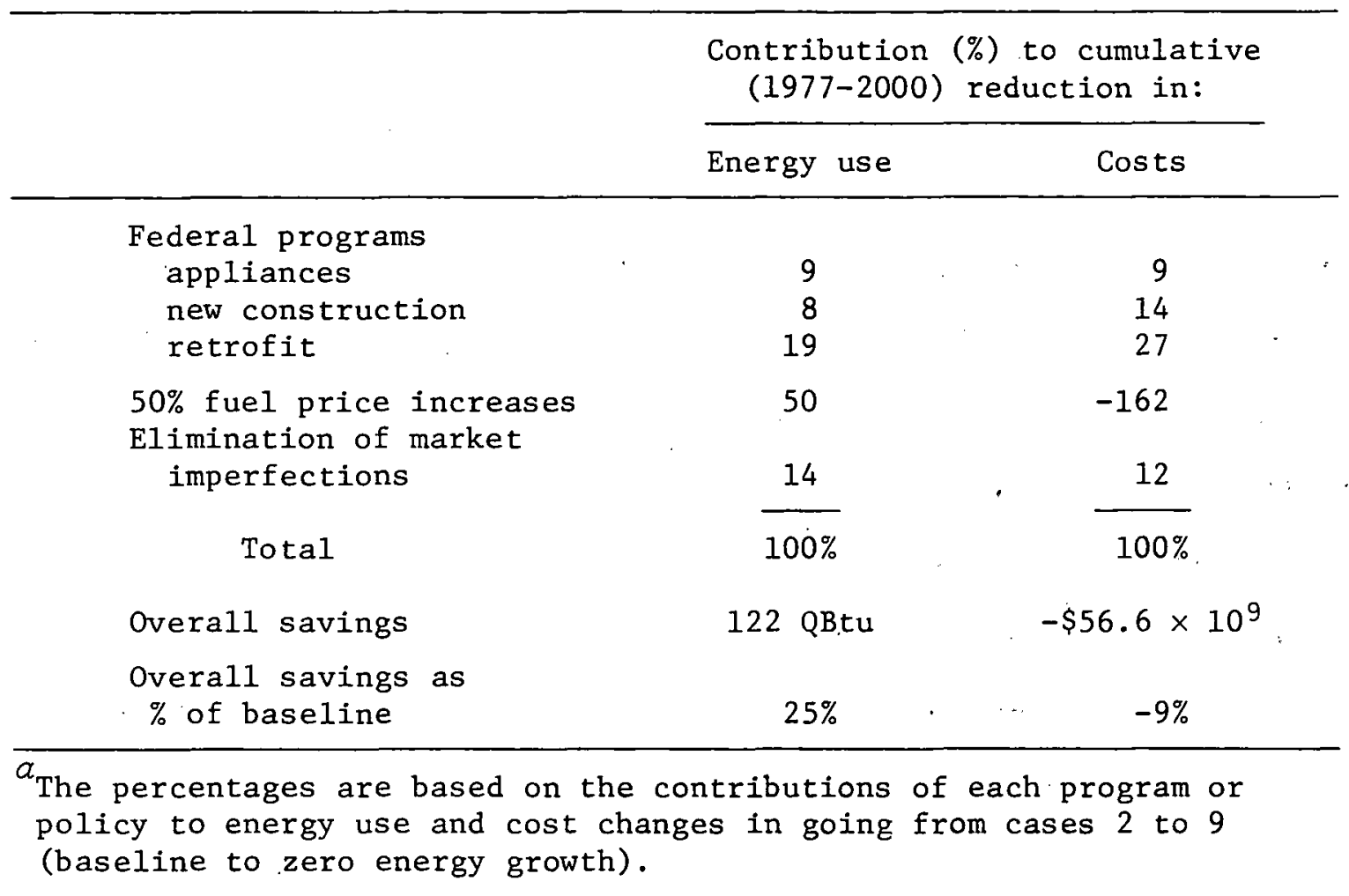

\section{ACKNOWLEDGMENTS}

We appreciate the careful reviews of this report from Roger Carlsmith, René Malès, James Boyd, Arthur Johnson, Jack Langmead, David Wood, Roger Sant, Lee Schipper, and William Klein. We also thank John Carlin and David Knapp for providing us with FEA estimates as inputs to our modeling effort. 


\section{REFERENCES}

1. The White House, The President's Energy Program, April 20, 1977. Also Executive Office of the President, The National Energy Plan, April 29, 1977.

2. E. Hirst, et al., An Improved Engineering-Economic Model of Residential Energy Use, Oak Ridge National Laboratory, ORNL/CON-8, April 1977.

3. E. Hirst and J. Jackson, "Historical Patterns of Residential and Commercia1 Energy Uses," Energy 2(2), June 1977.

4. Bureau of Mines, "Annual U.S. Energy Use Up in 1976," press release, U.S. Department of the Interior, March 14, 1977.

5. Bureau of the Census, "Projections of the Population of the United States: 1975-2050," Current Population Reports, Series P-25, No. 6n1, U.S. Department of Commerce, October 1975.

6. J. Carlin, personal communication, Federal Energy Administration, May 1977.

7. 94th Congress, Energy Policy and Conservation Act, PL 94-163, December 22, 1975.

8. 94th Congress, Energy Conservation and Production Act, PL 94-385, August 14, 1976.

9. Owens-Corning Fiberglas Corp., "Potential for Energy Conservation in Residential Construction," presentation to the Federal Energy Administration, February 25, 1977.

10. S. Carhart, personal communication, Brookhaven National Laboratory, March 4, 1977.

11. R. Hoskins and E. Hirst, Energy and Cost Analysis of Residential Water Heaters, Oak Ridge National Laboratory, ORNL/CON-10, June 1977.

12. D. Quigley, personal communication, Federal Energy Administration, March 1977.

13. A. D. Little, Inc., An Impact Assessment of ASHRAE 90-75, Energy Concervation in New Building Desigri, December 1975. A1so, A. D. Little, Inc., An Energy and Economic Assessment of HUD's Minimum Property Standards, October 1976.

14. Department of Housing and Urban Development, "Mobile Home Construction and Safety Standards," Federal Register, 40(244), December 18, 1975 . 
THIS PAGE

\section{WAS INTENTIONALLY \\ LEFT BLANK}


Appendix: Market Penetration Analysis in the ORNL Residential Energy Use Mode1

Version III of the ORNL residential energy use simulation model ${ }^{A 1}$ cannot endogenously evaluate changes in new equipment efficiencies and new structures thermal integrities over time. The model does evaluate changes in equipment choices and in equipment usage in response to fuel price changes. In addition, Version III can evaluate the energy and economic effects of introducing new residential energy technologies if the user specifies the rate of implementation (i.e., the number of such systems installed each year) for the new technology.

Version IV was developed to overcome these limitations in Version III: to provide a model that endogenously determines changes in new equipment and structures efficiencies in response to changes in fuel prices and the state of technologies (i.e., relationships between equipment or structure efficiency and capital cost). This appendix summarizes the operation of Version IV. Version IV is identical to Version III except for the changes discussed here.

There are three elements involved in the market penetration analysis:

Consumer behavior

Producer behavior

Demand/supply interaction.

Consumer behavior in the energy use model is represented by fuel price, equipment price, and income elasticities, as derived in refs. A2 and A3. Manufacturer behavior is determined in the model by supply curves that relate equipment (or structure) energy requirements to equipment (or structure) purchase price. These relationships were developed in a detailed fashion at ORNL for refrigerators ${ }^{\mathrm{A} 4}$ and water heaters. ${ }^{\wedge 5}$ 
Relationships for other end uses were developed from a review of the existing literature. ${ }^{A l}$

Version IV integrates the demand (consumer) and supply (manufacturer) sides to provide a dynamic equilibrium that determines efficiencies over time. There are two steps to this analysis. The first involves determination of average efficiencies for new equipment and structures for each year of the simulation. These efficiencies are functions of fuel prices, implicit interest rates (related to fuel price and equipment price elasticities), and the technology relationships.

The second step is determination of equipment choices for new installations for each year of the simulation. The model determines new equipment market-shares each year as functions of operating costs (efficiencies and fuel prices) and capital costs, as well as household income. ${ }^{\mathrm{A} 2}$

New Structures Efficiencies

Table A-1 summarizes the major elements of the demand and supply sides for new structures. The demand side is characterized by an interest rate and an investment lifetime, assumed to be $6 \%$ and 25 years, respectively. (These values are input to the model and can be readily changed. For example, one might hypothesize that consumers use only five years as their horizon for investment decision, although structures last much longer).

The supply side is represented by curves that relate thermal integrity to changes in capital cost for the residence; see Fig. 7 on page 26 . If the curve of Fig. 7 is rotated $90^{\circ}$, one obtains Fig. Al. Adding operating 
Table A-1. Assumed determinants of consumer and producer behavior with respect to thermal integrity of new structures

1. Consumer behavior

$$
\begin{aligned}
& \text { 6\% "real" interest rate } \\
& 25 \text {-year lifetime } \\
& \text { Assumptions can be readily changed in model }
\end{aligned}
$$

2. Supply-side behavior

relationship between structure performance and initial cost (e.g., Fig. 7)

costs (for space heating and air conditioning) to the capital cost relationship of Fig. Al yields the lifecycle cost (LCC) curve of Fig. $\mathrm{A} 2$.

Figure A2 shows the typical behavior of declining and then increasing LCC as capital cost changes. The point of minimum LCC is denoted by $\mathrm{T}$ optimal, the structure thermal integrity/capital cost point at which LCC is minimized. However, historical data show that the system does not operate at the optimal point; it operates at a point of higher thermal integrity (less efficient structure) and lower capital cost, denoted hy $T$ actual

We hypothesize that the difference between $\mathrm{T}_{\text {optimal }}$ and $\mathrm{T}_{\text {actual }}$ persists over time as fuel prices change. Figure A3 illustrates changes in $\mathrm{T}_{\text {optimal }}$ and $\mathrm{T}_{\text {actual }}$ as fuel prices change. As the price of fuel increases from $P_{0}$ to $P_{1}$ and $P_{2}$, $T_{\text {optimal moves to the left and so does }}$ $\mathrm{T}_{\text {actual }} \cdot \mathrm{T}_{\text {optimal }}$ is always the minimum on the LCC curve. $\mathrm{T}_{\text {actual }}$ is calculated from $T_{\text {optimal }}$ by assuming that $D$ (the vertical distance between $\mathrm{T}_{\text {optimal }}$ and $\mathrm{T}_{\text {actual }}$ ) varies inversely with fuel price: 


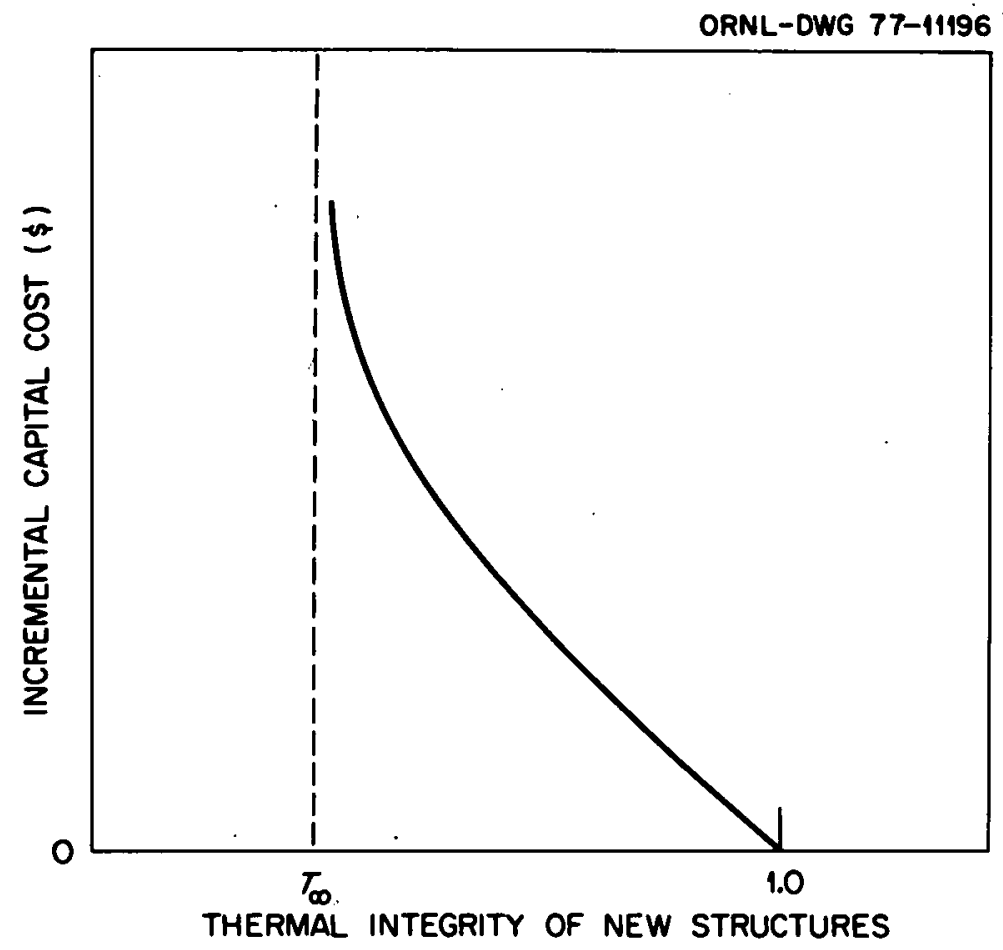

Fig. Al. Relationship between thermal integrity and incrementa1 capital cost for new structures $(T=1.0$. refers to the 1970 condition).

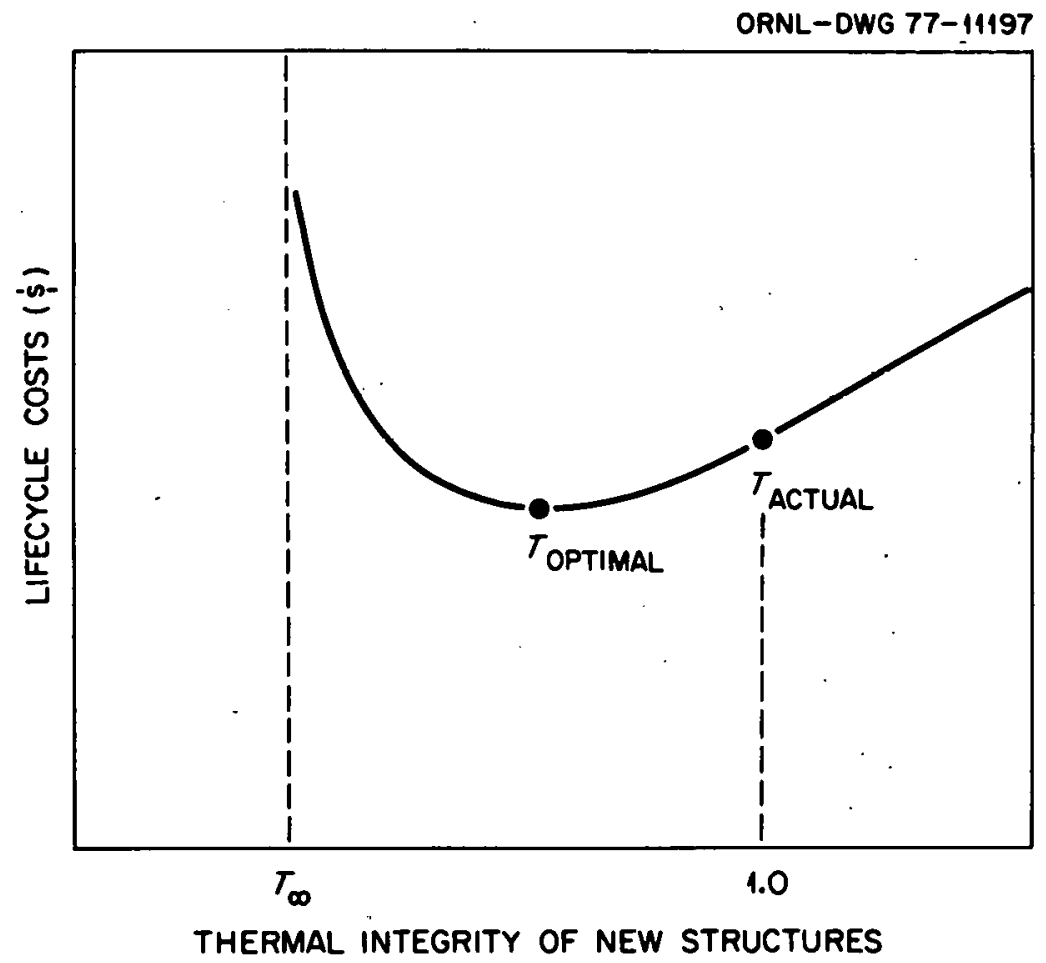

Fig. A2. Lifecycle costs for heating and cooling residences as a function of thermal integrity. 


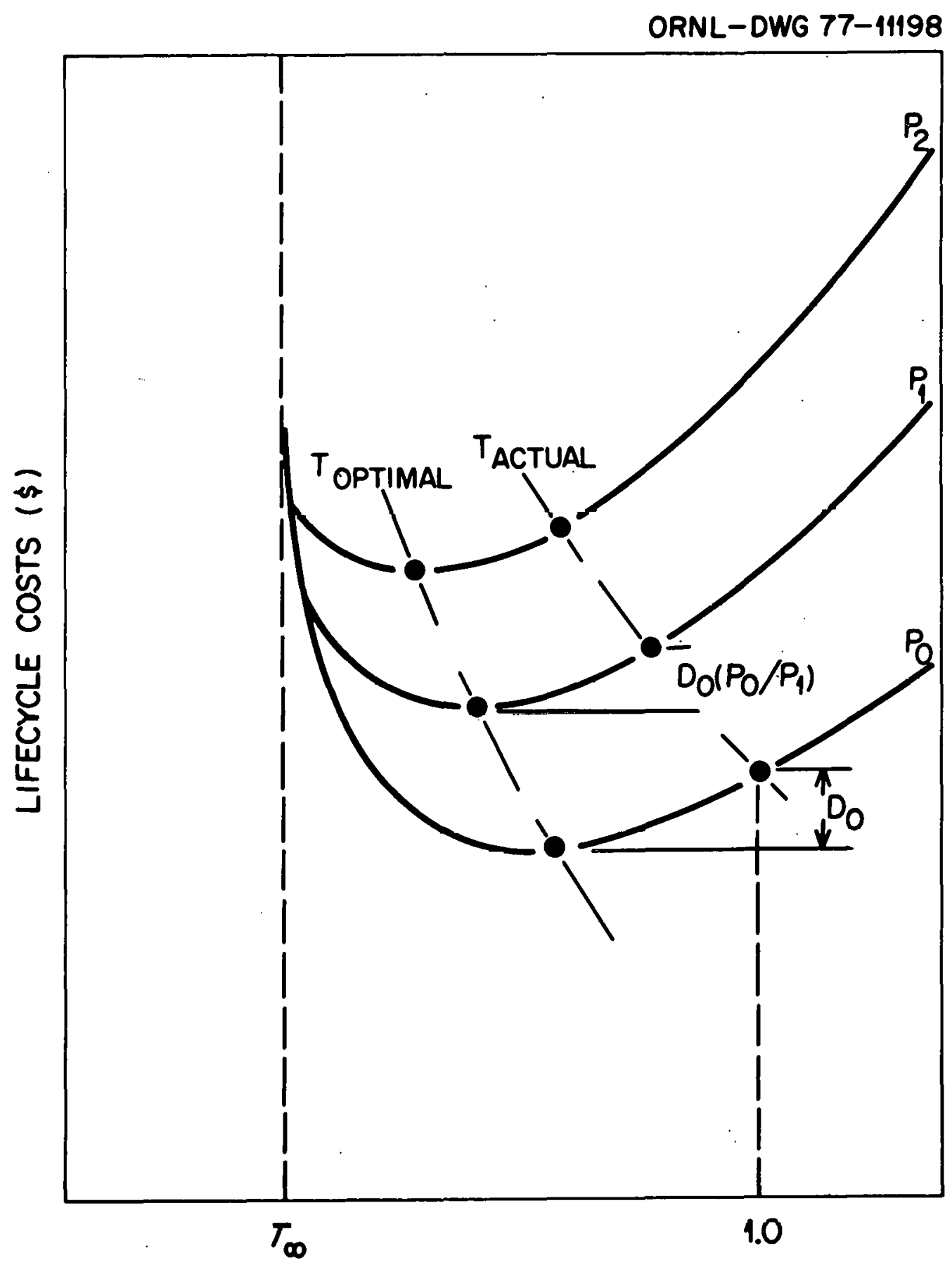

THERMAL INTEGRITY OF NEW STRUCTURES

Fig. A3. Changes in thermal integrity of new structures as a function of fuel price. 
$D=D_{0}\left(P_{0} / P\right)$

Thus as fuel prices increase, the "distortion" between the optimal and actual states will decline.

D represents the difference between the actual and optimal states. We hypothesize the (non-zero) existence of $\mathrm{D}$ because of market imperfections on both the demand and supply sides: lack of consumer information, costs of processing information, lack of incentive for producers to operate at the optimal point, lack of motivation from financial institutions, etc. We also assume that as fuel prices rise, these market imperfections will be reduced.

New Equipment Efficiencies

The model operates in a similar fashion in determining efficiencies of new equipment. However, an additional step is involved: determination of new equipment market-shares. Market-shares are determined in the energy model as functions of capital and operating costs for each choice and per capita personal income (from ref. A2):

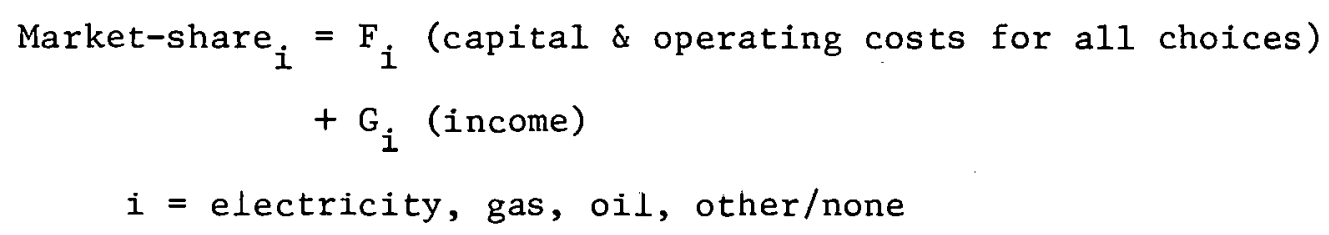

These relationships yield lines of constant market-shares as operating and capital costs for the system change (assuming that the characteristics of competing systems and incomes do not change). The slope of these constant market-share lines determines the implicit interest rate 
at which consumers trade off operating for capital costs (Table A-2 and Fig. A4). Al $^{\text {. }}$

Table A-2. Real interest rates used in the ORNL residential energy model to determine equipment price elasticities

\begin{tabular}{|c|c|c|c|}
\hline & \multicolumn{3}{|c|}{ Real interest rate $(\%)$ for: } \\
\hline & Electric & Gas & Oil \\
\hline \multicolumn{4}{|l|}{ Space heating } \\
\hline Electric & 8 & 11 & 11 \\
\hline Gas & 11 & 8 & 11 \\
\hline Oi1 & 11 & 11 & 8 \\
\hline \multicolumn{4}{|l|}{ Water heating } \\
\hline Electric & 12 & 15 & 15 \\
\hline Gas & 15 & 12 & 15 \\
\hline Oil & 15 & 15 & 12 \\
\hline Refrigeration & 15 & & \\
\hline Freezing & 15 & & \\
\hline \multicolumn{4}{|l|}{ Cooking } \\
\hline Electric & 15 & 18 & \\
\hline Gas & 18 & 15 & \\
\hline \multicolumn{4}{|c|}{ Air conditioning } \\
\hline Room & 15 & 15 & \\
\hline Central & 18 & 12 & \\
\hline Lighting & 15 & . & \\
\hline \multicolumn{4}{|l|}{ Other } \\
\hline Elcctric & 15 & & \\
\hline Gas & & 15 & \\
\hline
\end{tabular}

Source: ref. Al.

The supply side is represented. by curves that relate equipment energy requirements to equipment purchase prices; Figs. 5 and 6 (pages 22 and 23) show such relationships for water heaters. A5

Once again, the demand and supply relationships can be combined on a single graph (shown in Fig. A5) to determine the intersection. In 


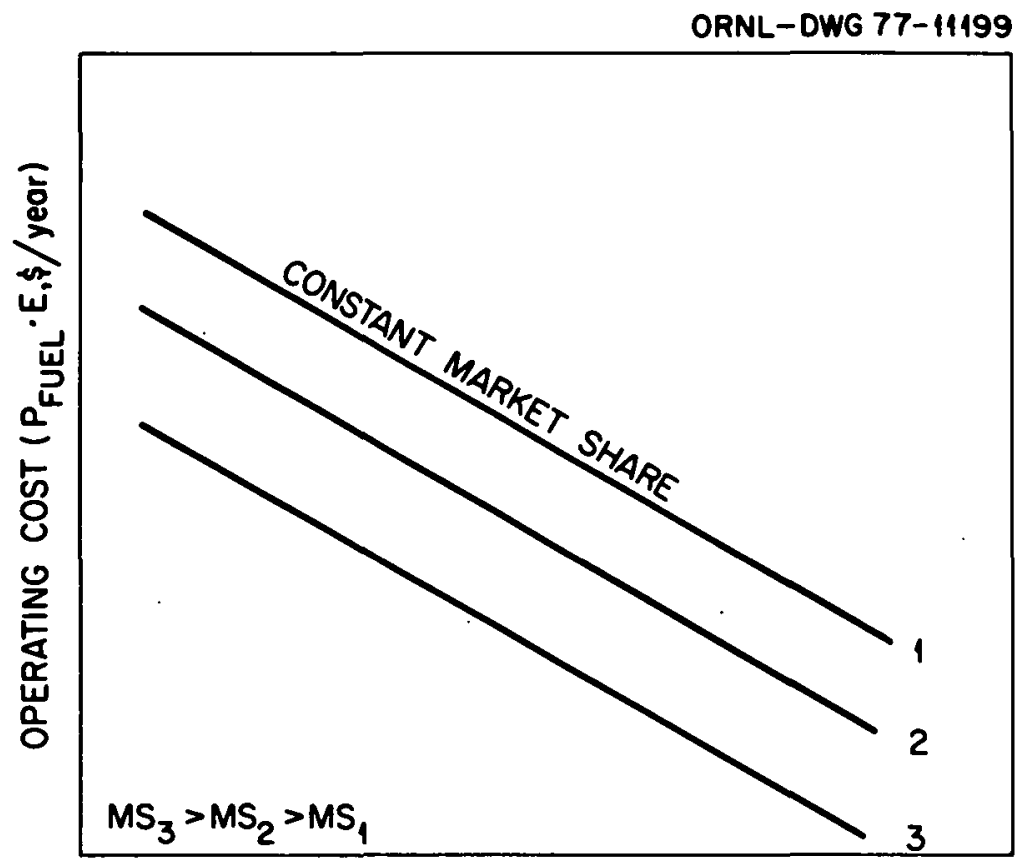

EQUIPMENT COST (\$)

Fig. A4. Consumer preferences (market-shares) as a function of equipment operating and capital costs.

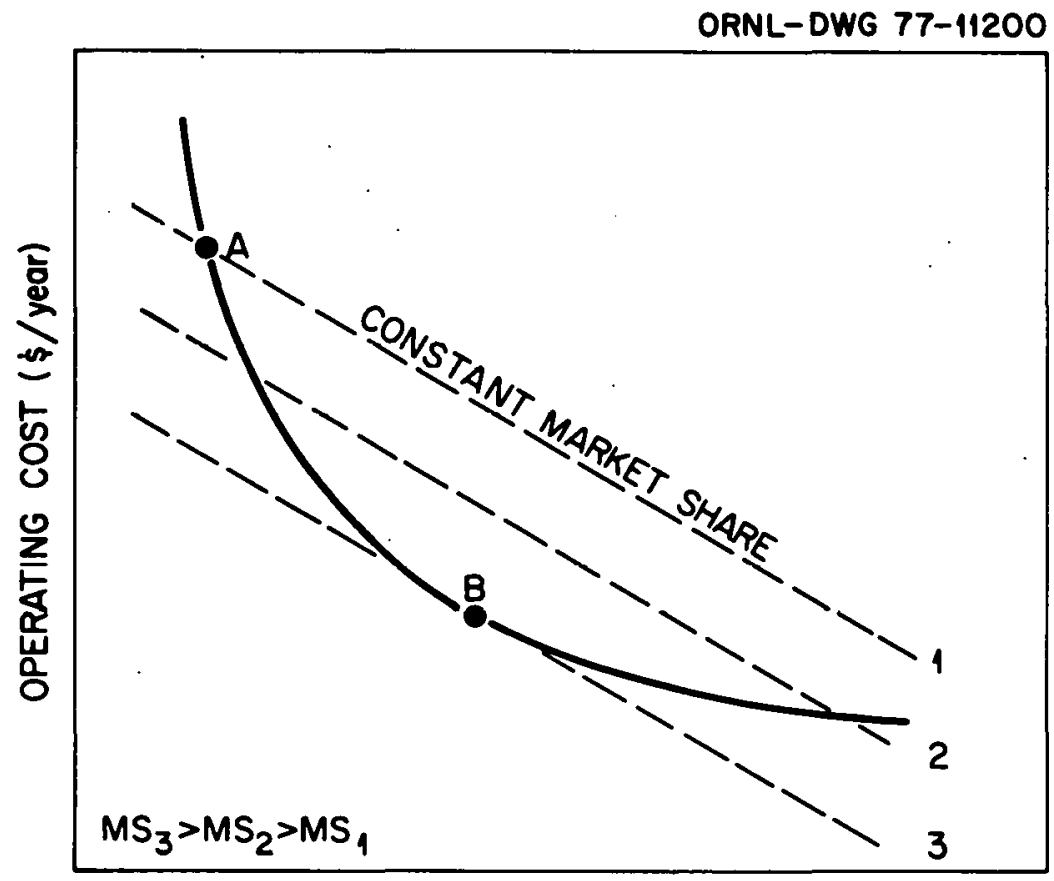

EQUIPMENT COST (\$)

Fig. A5. Intersections between consumer preferences and technology relationships for new equipment (Point A represents the 1970 "equilibrium," point B represents the "optimal"). 
Fig. A5, point A represents the actual intersection for a particular year (e.g., 1970). Point $B$ represents the optimal point, i.e., the point at which marginal improvements in equipment efficiency yield the consumer's implied rate of return.

Figure A6 shows how, as fuel prices change, the efficiency and market-share for this type of new equipment also change. Again, the difference between the actual and optimal states is denoted by $D . \quad D$ is assumed to vary inversely with fuel price. As fuel prices change, the optimal point (point of tangency between supply and demand curves) changes. Moving perpendicular from the optimal point the distance D yields the market-share line and efficiency for the new equipment.

Incorporation of this market penetration methodology into the ORNL residential energy use model allows us to evaluate the full range of responses to fuel price changes:

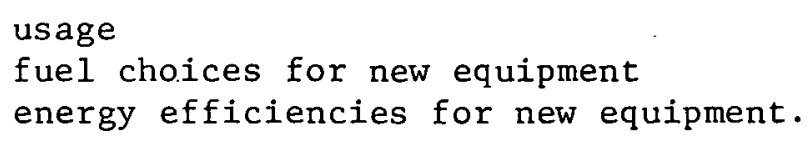

Figure A7 shows the model's prediction of the demand for gas to heat water in response to a step increase in the price of gas in year 0 . The price increase induces an initial response in terms of reduced hot water usage. This response reaches a peak five years after the price increase and then begins to subside.

The price increase induces two responses concerning new water heaters. Some households that would have purchased new gas water heaters switch to electric or oil water heaters. Those households selecting new gas water heaters choose more efficient units than they would have if the price of gas had not 1ncreased. These two equipment ownership responses 


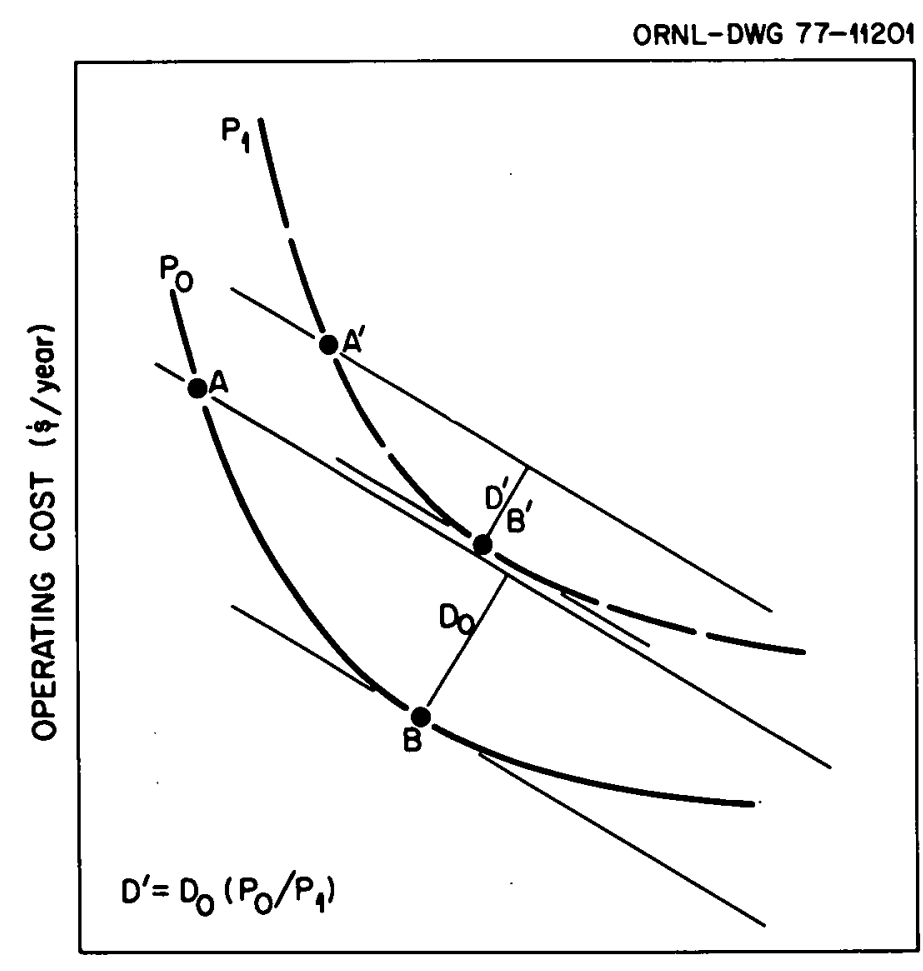

EQUIPMENT COST (\$)

Fig. A6. Changes in new equipment efficiencies and market-shares as functions of fuel price.

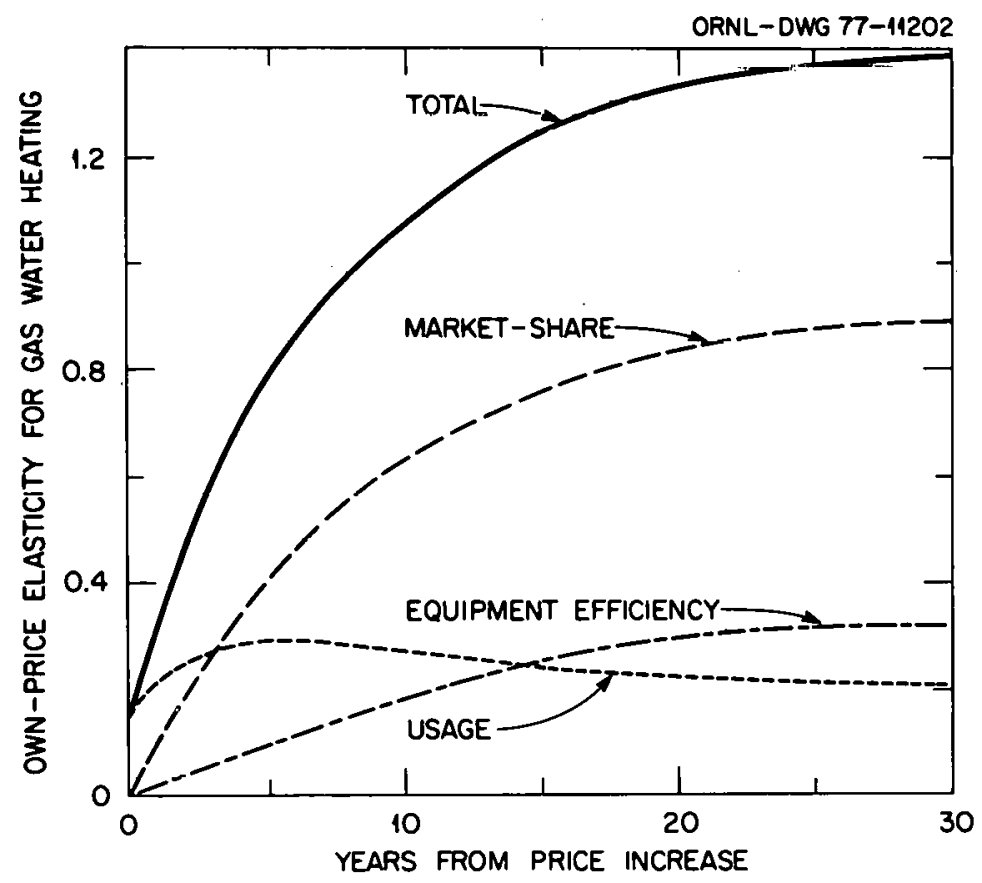

Fig. A7. Effects of a step change in the price of gas on ownership, efficiency, and usage of gas water heaters. 
occur much more slowly than does the usage response: ownership changes are limited by the lifetime of water heaters (half-life of seven years). Only as existing water heaters wear out can changes be made in terms of fuel choices and energy efficiencies.

As the average efficiency of gas water heaters improves, households adjust their usage accordingly. Thus, after 30 years the usage change is two-thirds its maximum value (after five years).

The top curve in Fig. A7 shows the total change in gas use for water heating in response to the price change. The total is the sum of the three individual responses. Figure A7 shows both the complexity of responses to a change in an exogenous variable and differences in dynamics for these responses. Usage responds rapidly while ownership changes occur much more slowly.

Table A-3 shows the long-run fuel price and income elasticities produced with the overall simulation model. These elasticities include all three responses discussed above. Long-run own-price elasticities are all equal to or greater than 1.0. The elasticity of demand for total residential energy use with respect to the price of all fuels is about -0.75 . Thus a $10 \%$ increase in the price of all fuels would cut residential energy demand by $7.5 \%$. This overall fuel price elasticity is about 50\% larger than the overall income elasticity of 0.52 . These elasticity estimates are in good agreement with those reported elsewhere. A3

\section{Additional Efforts}

Although the existing model (Version IV) seems to operate quite well, additional effort is required to both validate and improve the 
Table A-3. Long-run elasticities obtained with Version IV of the ORNL residential energy use model

\begin{tabular}{|c|c|c|c|c|c|}
\hline & \multicolumn{4}{|c|}{ Price of: } & \multirow[b]{2}{*}{ Income $^{a}$} \\
\hline & Electricity & Gas & Oil & All fuels & \\
\hline Electricity & -1.02 & 0.24 & 0.05 & -0.75 & 0.61 \\
\hline Gas & 0.21 & -1.05 & 0.15 & -0.71 & 0.80 \\
\hline Oil & 0.14 & 0.48 & -1.42 & -0.92 & -0.02 \\
\hline Total & -0.45 & -0.12 & -0.14 & -0.75 & 0.51 \\
\hline
\end{tabular}

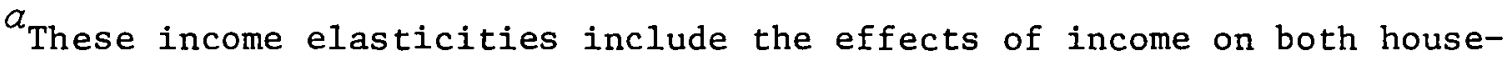
hold formation and fuel use per household.

model. As of now, we have not compared model predictions with historical data. We hope, during the next few months, to do this. We must also develop better equipment efficiency/capital cost relationships for the model because model results are quite sensitive to the shape of these curves. Additional efforts are also required to better define the consumer behavior relationships (elasticities) that are input to the modei.

\section{References}

A1. E. Hirst, et al., An Improved Engineering-Economic Model of Residential Energy Use, Oak Ridge National Laboratory, ORNL/CON-8, April 1977.

A2. W. Lin, E. Hirst, and S. Cohn, Fuel Choices in the Household Sector, Oak Ridge National Laboratory, ORNL/CON-3, October 1976.

A3. S. Cohn, E. Hirst, and J. Jackson, Econometric Analyses of Household Fuel Demands, Oak Ridge National Laboratory, ORNL/CON-7, February 1977.

A4. R. Hoskins and E. Hirst, Energy and Cost Analysis of Residential. Refrigerators, Oak Ridge National Laboratory, ORNL/CON-6, January 1977.

A5. R. Hoskins and E. Hirst, Energy and Cost Analysis of Residential Water Heaters, Oak Ridge National Laboratory, ORNL/CON-10, June 1977. 
ORNL/CON-13

\section{INTERNAL DISTRIBUTION}

1. S. I. Auerbach

2. S. E. Beall

3. D. J. Bjornstad

4. J. R. Buchanan

5. R. S. Carlsmith

6. J. Carney

7. W. S. Chern

8. T. J. Clifford

9. S. Cohn

10. J. Cope

11. C. G. Crafton

12. F. L. Culler

13. R. M. Davis

14. J. G. Delene

15. W. Fulkerson

16. G. S. Gill

17. M. Guthrie

18. V. 0 . Haynes

19. N. E. Hinkle

20. E. A. Hirst

21. J. R. Jackson

22. P. L. Johnson

23. S. I. Kaplan

24. D. Kaserman
25. R. S. Livingston

26. H. M. Long

27-47. P. M. Love

48. J. W. Michel

49. R. E. Minturn

50. W. R. Mixon

51. J. C. Moyers

52. E. A. Nephew

53. H. Postma

54. M. W. Rosenthal

55. T. H. Row

56. R. L. Spore

57. E. G. Struxness

58. D. B. Trauger

j9. G. U. UIrikson

60. D. J. Walukas

61. H. E. Zittel

62. A. Zucker

63. Biology Division Library

64-65. Central Research Library

66. Document Reference Section

67. Laboratory Records, (RC)

68-70. Laboratory Records Dept.

71. ORNL Patent Office

\section{EXTERNAL DISTRIBUTION}

72. Institute of Energy Analysis, ORAU-Library

73. Research and Technical Support Division, ERDA-ORO

74-100. Technical Information Center, ERDA, P. 0. Box 62, Oak Ridge, Tennessee 378.30

101-600. External Energy Conservation Distribution Mailing List and Energy Conservation Office. (4500N, H-32) 